\title{
Interactions between Ras1, dMyc, and dPI3K signaling in the developing Drosophila wing
}

\author{
David A. Prober ${ }^{1}$ and Bruce A. Edgar ${ }^{2,3}$ \\ ${ }^{1}$ Molecular and Cellular Biology Program, University of Washington, Seattle, Washington 98195, USA; ${ }^{2}$ Division of Basic \\ Sciences, Fred Hutchinson Cancer Research Center, Seattle, Washington 98109, USA
}

The Ras GTPase links extracellular signals to intracellular mechanisms that control cell growth, the cell cycle, and cell identity. An activated form of Drosophila Ras $\left(\operatorname{Ras}^{\mathrm{V} 12}\right)$ promotes these processes in the developing wing, but the effector pathways involved are unclear. Here, we present evidence indicating that $\operatorname{Ras}^{\mathrm{V} 12}$ promotes cell growth and $G_{1} / S$ progression by increasing $d M y c$ protein levels and activating $\mathrm{dPI} 3 \mathrm{~K}$ signaling, and that it does so via separate effector pathways. We also show that endogenous Ras is required to maintain normal levels of $\mathrm{dMyc}$, but not dPI3K signaling during wing development. Finally, we show that induction of dMyc and regulation of cell identity are separable effects of Raf/MAPK signaling. These results suggest that Ras may only affect PI3K signaling when mutationally activated, such as in Ras ${ }^{\text {12 }}$-transformed cells, and provide a basis for understanding the synergy between Ras and other growth-promoting oncogenes in cancer.

[Key Words: Ras; Myc; PI3K; Drosophila; cell growth; cell cycle]

Received March 14, 2002; revised version accepted July 3, 2002.

Cancer is a genetic disease resulting from inappropriate activation or overexpression of proto-oncogenes, compounded by loss of tumor suppressor gene activity (Hanahan and Weinberg 2000). This process is often facilitated by mutation of so-called mutator genes, resulting in genomic instability and accelerated rates of genetic mutation. A great deal has been learned about interactions among various oncogenes including Ras, Myc, and members of the PI3K-signaling pathway that may contribute to oncogenesis. Most of these studies have been performed in vitro and in mammalian cell culture systems, however, and detailed in vivo analysis is lacking. It is also unclear whether these genes interact during normal development as they do when activated or overexpressed in tumors.

Ras is a membrane-associated guanine nucleotidebinding protein that is normally activated in response to the binding of extracellular signals, such as growth factors, to receptor tyrosine kinases. These receptors include the epidermal growth factor receptor (EGFR) in mammals and its Drosophila homologs dEGFR/DER, Sevenless, and Torso. Phosphotyrosine residues on activated receptors bind $\mathrm{SH} 2$ domains of adaptor proteins such as Drk/Grb2, which, via their SH3 domains, bind

${ }^{3}$ Corresponding author.

E-MAIL bedgar@fhcrc.org; FAX (206) 667-3308.

Article and publication are at http://www.genesdev.org/cgi/doi/10.1101/ gad.991102. guanine-nucleotide exchange factors such as Sos. Sos catalyzes the conversion of Ras from a GDP-bound inactive state to a GTP-bound active state, resulting in conformational changes in two so-called switch domains (Boriack-Sjodin et al. 1998). GTP-bound mammalian Ras recruits several effector proteins including Raf, PI3K, and RalGDS to the cell membrane, in which they become activated by either Ras-induced conformational changes (Pacold et al. 2000) or other membrane-associated proteins (Morrison and Cutler 1997). Mutations in Ras that cause constitutive GTP binding result in constitutive signaling to downstream effector proteins and are frequently found in a range of human tumors (Barbacid 1987).

Ras signaling affects many cellular functions, including cell proliferation, apoptosis, migration, fate specification, and differentiation (for review, see Rommel and Hafen 1998). Some of these effects have been shown to require the combined activation of several Ras effector proteins. For example, studies in NIH3T3 fibroblasts showed that activation of both Raf and PI3K is required for Ras-dependent transformation (Rodriguez-Viciana et al. 1997) and contributes to cell cycle progression (Gille and Downward 1999). Specific Ras effectors have also been shown to perform distinct functions. For example, Ras stimulates membrane ruffling and inhibits apoptosis via PI3K in fibroblast cells (Kauffmann-Zeh et al. 1997; Rodriguez-Viciana et al. 1997). However, several studies contradict these findings. For example, stimulation of 
either Raf or PI3K signaling alone is sufficient to induce cell proliferation in cultured postmitotic chicken neuroretina cells (Peyssonnaux et al. 2000), and Raf has been implicated in both promoting and inhibiting apoptosis in several cell types (Kauffmann-Zeh et al. 1997; Zhong et al. 2001). Such discrepancies may reflect cell-type specificities or indicate shortcomings of studying signaling pathways in cell culture. To clarify the roles of effector proteins in mediating Ras signaling, it may be useful to study Ras and its downstream effectors in vivo during normal growth and development. Genetic analyses in vivo have already revealed novel functions for Ras, including the ability to regulate cellular growth (i.e., mass accumulation; Hunter et al. 1995; Heumann et al. 2000; Prober and Edgar 2000), although it is not known which effector proteins mediate this function.

PI3Ks are a family of intracellular signal transducers that are activated by receptor tyrosine kinases and Gprotein-coupled receptors (for review, see Vanhaesebroeck et al. 2001). PI3Ks phosphorylate inositol lipids in the cell membrane, generating a range of second messengers including phosphatidylinositol-3,4,5-triphosphate $\left(\mathrm{PIP}_{3}\right) . \mathrm{PIP}_{3}$ recruits and activates downstream effectors such as Akt/PKB by binding to their pleckstrin homology $(\mathrm{PH})$ domains. Studies in both mice and Drosophila have implicated this pathway in growth regulation, presumably due to its ability to promote glucose and lipid import, nutrient storage, and translation of RNAs involved in ribosome biogenesis (Vanhaesebroeck et al. 2001). Several lines of evidence implicate this pathway as a causal factor in cancer. For example, Akt/PKB was discovered as a viral oncogene, and PTEN, a lipid phosphatase that antagonizes PI3K signaling, is a tumor suppressor implicated in many human cancers and two cancer-associated inherited diseases (Cantley and Neel 1999).

Studies in cell culture have implicated the Myc family of transcription factors as regulators of the cell cycle that are rapidly induced in response to growth factors (for review, see Grandori et al. 2000). These studies are supported by the recent finding that mice with reduced Myc function have defects in cell proliferation (Trumpp et al. 2001). Several studies of Drosophila and mammalian Myc in vivo have also shown a critical function in regulating cell growth (Iritani and Eisenman 1999; Johnston et al. 1999; Kim et al. 2000; de Alboran et al. 2001; Douglas et al. 2001). These roles are supported by analyses of Myc target genes, which include regulators of both cell growth and the cell cycle (Coller et al. 2000; Boon et al. 2001). Myc is also a potent oncogene that is rearranged and overexpressed in a wide range of tumors.

The fact that Ras, Myc, and PI3K have all been implicated in regulating cell growth and the cell cycle suggests that they may interact with each other. In support of this idea, studies in mammalian cell culture have shown that Ras can stabilize Myc protein (Sears et al. 2000) and directly bind to and activate PI3K (RodriguezViciana et al. 1994; Pacold et al. 2000). However, genetic evidence suggesting that Ras regulates Myc or PI3K in vivo is lacking. Ras signaling plays a major role in cell fate specification in Drosophila and Caenorhabiditis elegans (Rommel and Hafen 1998). In contrast, PI3K signaling does not regulate cell fate in C. elegans, and the Drosophila Myc and PI3K homologs regulate cell growth but not cell fate (for review, see Prober and Edgar 2001). The ability of Drosophila Ras to regulate both patterning and growth, however, raises the possibility that Ras might regulate growth via $\mathrm{dMyc}$ and/or dPI3K. Here we show that an activated form of Drosophila Ras is capable of driving growth via both $\mathrm{dMyc}$ and the $\mathrm{dPI} 3 \mathrm{~K}$ pathway, and that endogenous Ras is required to maintain normal levels of dMyc, but not dPI3K signaling, during wing development.

\section{Results}

Activated Ras increases dMyc levels and activates dPI3K signaling

Substitution of valine for glycine at position 12 of mammalian Ras, which is frequently observed in tumors, inhibits GTP hydrolysis and results in constitutive activity (Barbacid 1987). We have shown previously that ectopic expression of a Drosophila Ras1 transgene containing this mutation (Ras ${ }^{\mathrm{V} 12}$; Karim and Rubin 1998) accelerates the $G_{1} / S$ transition of the cell cycle, increases cell size, and increases clonal growth rates in the developing Drosophila wing (Prober and Edgar 2000). Because overexpression of the Drosophila homologs of Myc (dMyc) and PI3K (dPI3K) have similar but stronger effects (Johnston et al. 1999; Weinkove et al. 1999; Fig. 1A), we examined whether they mediate the effects of Ras $^{\mathrm{V} 12}$.

To examine the effect of Ras ${ }^{\mathrm{V} 12}$ expression on $\mathrm{dMyc}$ and dPI3K, we generated clones of cells expressing Ras $^{\mathrm{V} 12}$ using the Flp/Gal4 technique (Struhl and Basler 1993; Pignoni and Zipursky 1997; Neufeld et al. 1998). This technique allows generation of permanent, heritable expression of UAS-regulated transgenes in random clones of cells in response to a heat shock. As we have shown previously, ectopic expression of Ras ${ }^{\mathrm{V} 12}$ increases dMyc protein levels (Fig. 1C). To assay dPI3K signaling in vivo, we used a reporter stock that constitutively expresses a transgene encoding the pleckstrin-homology (PH) domain from the Drosophila homolog of general receptor for phosphoinositides-1 (GRP1) fused to GFP (tGPH; Britton et al. 2002). The PH domain of mammalian GRP1 specifically binds $\mathrm{PIP}_{3}$ (Ferguson et al. 2000; Lietzke et al. 2000), which is the second messenger generated by $\mathrm{PI} 3 \mathrm{~K}$. Because $\mathrm{PIP}_{3}$ is generally located in lipid membranes, particularly the cell membrane, GRP1 is recruited to the cell membrane when PI3K activity increases cellular $\mathrm{PIP}_{3}$ levels. Fusion proteins containing the GRP1 PH domain are recruited similarly to cell membranes by binding PIP $_{3}$, and thus serve as in situ reporters for PI3K activity (Gray et al. 1999; Oatey et al. 1999). The tGPH reporter binds PIP $_{3}$ with high affinity in vitro (W. Lockwood and S. Cohen, pers. comm.) and responds to increases or decreases in dPI3K signaling in vivo by increasing or decreasing its localization at the 


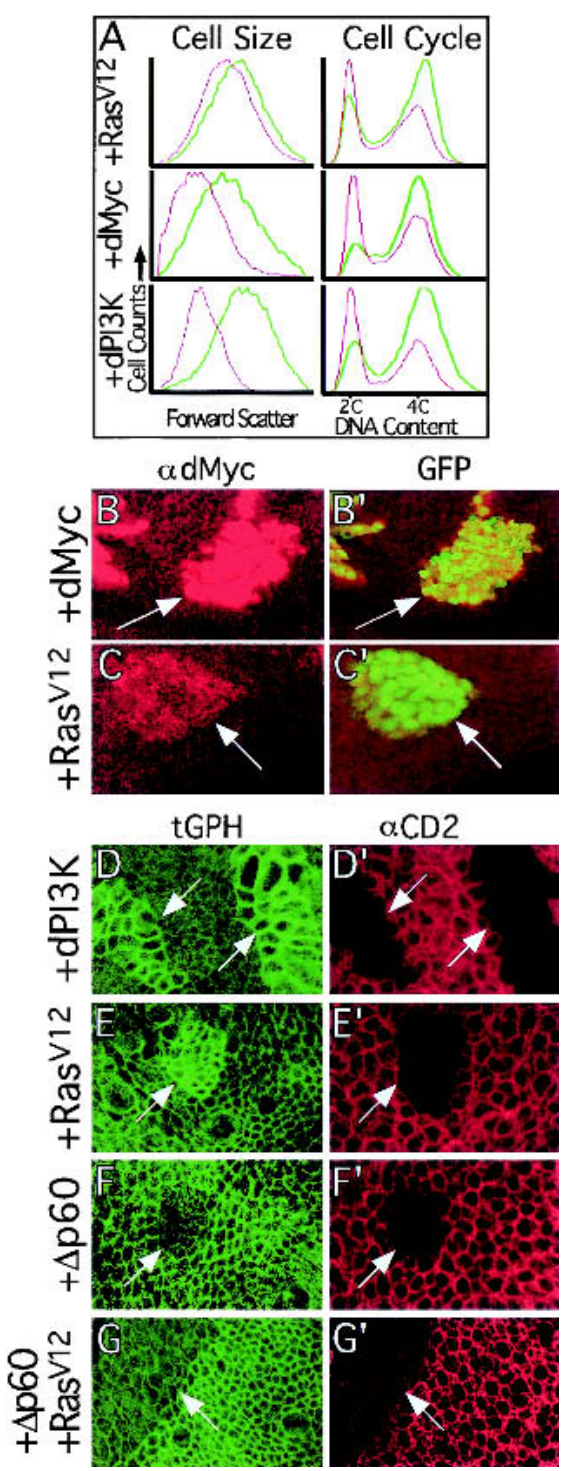

Figure 1. Ras ${ }^{\mathrm{V} 12}$ expression increases $\mathrm{dMyc}$ protein levels and activates dPI3K signaling. (A) FACS analysis of wing disc cells overexpressing Ras ${ }^{\mathrm{V} 12}$, dMyc, or dPI3K. Green and red traces represent $\mathrm{GFP}^{+}$(experimental) and $\mathrm{GFP}^{-}$(control) cells, respectively. Each trace is normalized to fit the graph as the numbers of $\mathrm{GFP}^{+}$and $\mathrm{GFP}^{-}$cells analyzed for each sample were not exactly equal. (Left) Cell size. Forward scatter data, which gives a relative measure of cell size, shows that expression of Ras ${ }^{\mathrm{v} 12}$, dMyc, or dPI3K increases cell size. (Right) Cell cycle. DNA content data, which shows the proportion of cells in $\mathrm{G}_{1}(2 \mathrm{C})$ and $\mathrm{G}_{2}(4 \mathrm{C})$, indicates that expression of Ras ${ }^{\mathrm{V} 12}, \mathrm{dMyc}$, or dPI3K decreases the proportion of cells in $\mathrm{G}_{1} .(B, C)$ Flp/Gal4 clones (marked with GFP in $B^{\prime}$ and $\left.C^{\prime}\right)$ expressing either $\mathrm{dMyc}\left(B, B^{\prime}\right)$ or $\operatorname{Ras}^{\mathrm{V} 12}\left(C, C^{\prime}\right)$ show increased staining with a dMyc-specific antibody $(B, C)$. $(D-G)$ Flp/Gal4 clones (marked by loss of the CD2 cell membrane marker in $\left.D^{\prime}, E^{\prime}, F^{\prime}, G^{\prime}\right)$ expressing either dPI3K $(D)$ or Ras ${ }^{\mathrm{v} 2}(E)$ have increased cell membrane-associated tGPH, a PH-GFP fusion protein used as an indicator of dPI3K signaling. In contrast, clones expressing either $\Delta \mathrm{p} 60(F)$ or $\Delta \mathrm{p} 60+\operatorname{Ras}^{\mathrm{V} 12}(G)$ have reduced cell membrane-associated tGPH. Note that apical tGPH and lateral $\alpha \mathrm{CD} 2$ sections are shown, resulting in slight misalignment of tGPH and $\alpha \mathrm{CD} 2$ in these images. Magnification: $B, C, 40 \times ; D-G, 100 \times$. cell membrane (Britton et al. 2002). In normal wing disc cells, we observed tGPH fluorescence throughout the entire cell membrane (Fig. 2A). Higher tGPH levels colocalized with Armadillo, however, which is located in adherens junctions at the apical region of the cell membrane (Fig. 2A). This suggests that dPI3K signaling is normally most active at the apical region of wing disc cells. To determine whether the observed tGPH fluorescence in wild-type cells reflects endogenous dPI3K activity, we inhibited $\mathrm{dPI} 3 \mathrm{~K}$ activity by expressing $\Delta$ p60. p60 is an adapter protein that links the catalytic subunit of dPI3K (Dp110) to upstream activators such as the Drosophila Insulin receptor (dInr) and the IRS homolog Chico. $\Delta \mathrm{p} 60$ is a variant of p60 that lacks the Dp110 interaction domain and inhibits dPI3K activity, presumably by preventing endogenous Dp110 from binding to and becoming activated by dInr and Chico (Weinkove et al. 1999). Overexpression of $\Delta$ p60 (Figs. 1F, 2D) reduced tGPH fluorescence throughout the cell membrane, indicating that much of the membrane-associated tGPH in wildtype discs results from the activity of endogenous dPI3K. Similar results were obtained upon overexpression of dPTEN, a lipid phosphatase that dephosphorylates $\mathrm{PIP}_{3}$ (data not shown).

Overexpression of dPI3K (Fig. 1D) resulted in strong recruitment of tGPH to the cell membrane. Expression of Ras ${ }^{\mathrm{V} 12}$ also resulted in high tGPH levels at the cell membrane (Fig. 1E), suggesting that $\mathrm{Ras}^{\mathrm{V} 12}$ activates dPI3K signaling, and thus increases $\mathrm{PIP}_{3}$ levels. To verify that these effects did not result simply from increased overall levels of the tGPH reporter, we performed Western blots on wing discs in which most cells overexpressed either dPI3K or Ras ${ }^{\mathrm{V} 12}$. Overexpressed dPI3K or Ras $^{\mathrm{V} 12}$ did not increase tGPH levels relative to controls (Supplemental Fig. 1 in Supplementary Material at http://www.genesdev.org). This result is consistent with our interpretation that increased levels of membraneassociated tGPH in response to Ras ${ }^{\mathrm{V} 12}$ and $\mathrm{dPI} 3 \mathrm{~K}$ results from relocalization and not increased levels of the reporter. These results suggest that $\mathrm{Ras}^{\mathrm{V} 12}$ activates dPI3K, consistent with experiments in mammalian systems, showing that Ras ${ }^{\mathrm{V} 12}$ can directly bind to and activate dPI3K (Rodriguez-Viciana et al. 1994; Pacold et al. 2000). However, we cannot rule out other potential mechanisms that may explain how Ras $^{\mathrm{V} 12}$ recruits tGPH to the cell membrane, such as inhibition of the lipid phosphatase dPTEN.

Overexpression of dPI3K increased tGPH fluorescence throughout the entire cell membrane, including both apical and basolateral regions (Fig. 2B). In contrast, $\mathrm{Ras}^{\mathrm{V} 12}$ only recruited tGPH to the apical region of the cell membrane (Fig. 2C), in which tGPH colocalized with Armadillo (data not shown). This effect did not result simply from recruitment of overexpressed Ras ${ }^{\mathrm{V} 12}$ to apical regions, as overexpressed $\mathrm{Ras}^{\mathrm{V} 12}$ was distributed throughout the cell membrane (Supplemental Fig. 2 in Supplementary Material at http://www.genesdev.org). These results suggest that Ras may require other apically localized factors to activate $\mathrm{dPI} 3 \mathrm{~K}$ signaling, although other explanations are possible. 


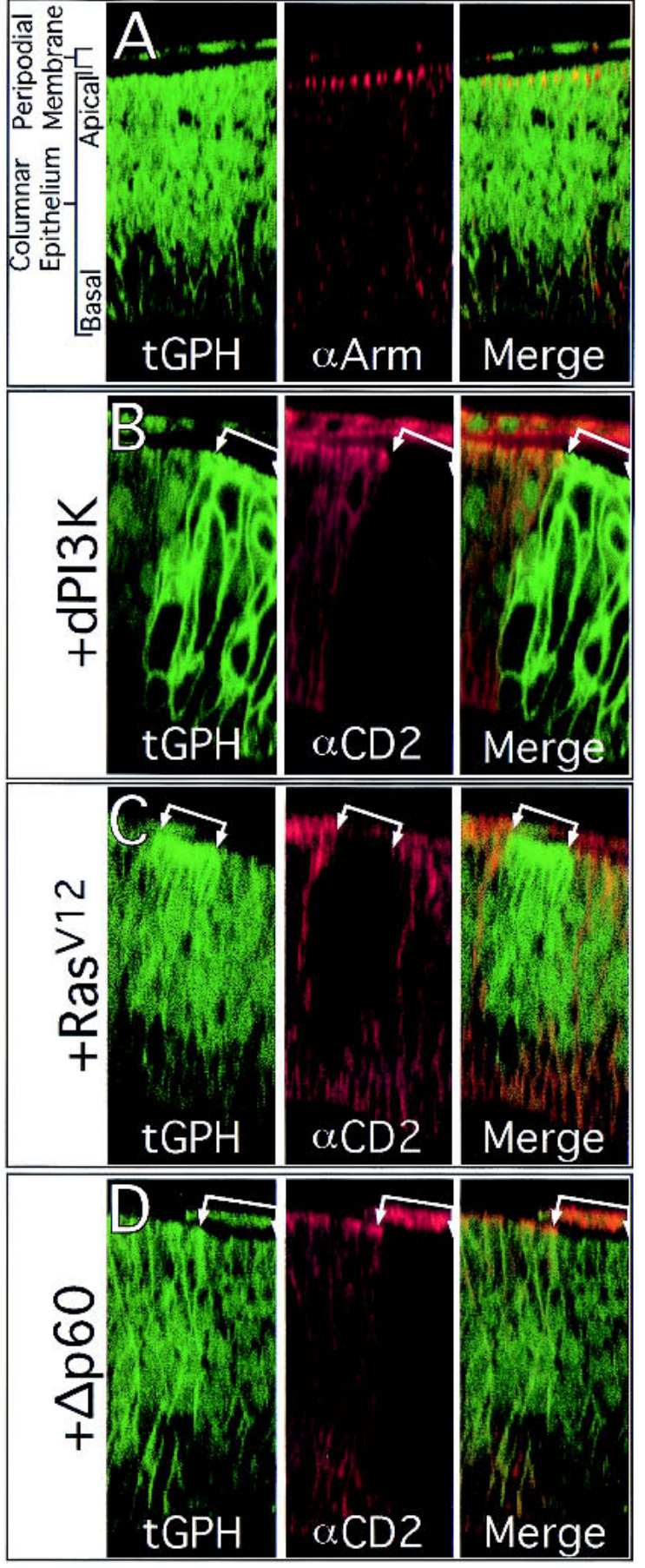

Figure 2. Subcellular localization of tGPH. $(A)$ Optical crosssections showing that tGPH is localized throughout the cell membranes, cytoplasm, and nuclei of cells in the columnar epithelium and peripodial membrane of imaginal wing discs. Intense GFP fluorescence is present at the apical region of the cell membrane, colocalizing with Armadillo, a component of apically localized adherens junctions. $(B-D)$ Flp/Gal4 clones (marked by loss of CD2) overexpressing dPI3K have strong tGPH fluorescence throughout the entire cell membrane $(B)$. Clones expressing Ras ${ }^{\mathrm{V} 12}$ have increased tGPH fluorescence at the apical region of the cell membrane $(C)$. Clones expressing $\Delta$ p60 have reduced tGPH fluorescence throughout the cell membrane $(D)$. Magnification, 100x.
To verify that the ability of $\mathrm{Ras}^{\mathrm{V} 12}$ to induce tGPH relocalization was dependent on $\mathrm{dPI} 3 \mathrm{~K}$ signaling, we coexpressed Ras ${ }^{\mathrm{V} 12}$ and $\Delta \mathrm{p} 60 . \Delta \mathrm{p} 60$ completely blocked the ability of coexpressed Ras ${ }^{\mathrm{V} 12}$ to recruit tGPH to the cell membrane (Fig. 1G), indicating that the ability of Ras ${ }^{\mathrm{V} 12}$ to relocalize tGPH is dependent upon dPI3K signaling. These experiments therefore show that $\mathrm{Ras}^{\mathrm{V} 12}$ is capable of increasing dMyc levels and activating dPI3K signaling in the developing wing.

\section{Ras $^{V 12}$ effector loop mutants activate different effector pathways}

Several mutations in the effector loop region of mammalian Ras have been identified that prevent Ras from binding and activating specific downstream effectors (White et al. 1995). For example, Ras ${ }^{\mathrm{V} 12 \mathrm{~S} 35}$ specifically binds and activates mammalian Raf, but not RalGDS or PI3K (Rodriguez-Viciana et al. 1997; Kinashi et al. 2000; Pacold et al. 2000). Ras ${ }^{\mathrm{V} 12 \mathrm{G} 37}$ interacts specifically with RalGDS (resulting in activation of the Ral GTPase; Rodriguez-

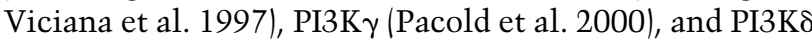
(Kinashi et al. 2000), but not with PI3K $\alpha$ or Raf. A third variant, Ras ${ }^{\mathrm{V} 12 \mathrm{C} 40}$, specifically interacts with $\mathrm{PI} 3 \mathrm{~K} \alpha$ but not with PI3K $\gamma, \mathrm{PI} 3 \mathrm{~K} \delta$, Raf, or RalGDS. The amino acid sequence of the effector loop region of Drosophila Ras is identical to that of mammalian Ras, and transgenic flies containing UAS-regulated forms of these variants have been generated, all containing the activating V12 mutation (Karim and Rubin 1998).

To determine whether the Ras ${ }^{\mathrm{V} 12}$ effector loop mutants specifically activate different Ras effector pathways in vivo, we generated clones of cells expressing the Ras ${ }^{\mathrm{V} 12}$ effector loop mutant transgenes in the developing wing and assayed their abilities to activate MAPK and dPI3K signaling. Staining with an antibody that recognizes the activated form of MAPK (dp-ERK) revealed that $\mathrm{Ras}^{\mathrm{V} 12}$, an activated form of Raf (Raf $\left.{ }^{\mathrm{GOF}}\right)$, and Ras ${ }^{\mathrm{V} 12 \mathrm{~S} 35}$ activated MAPK throughout the developing wing, whereas dPI3K and Ras ${ }^{\mathrm{V} 12 \mathrm{G} 37}$ did not (Fig. 3A,B; data not shown). Conversely, expression of Ras ${ }^{\mathrm{V} 12}$ or Ras ${ }^{\mathrm{V} 12 \mathrm{G} 37}$, but not Raf ${ }^{\mathrm{GOF}}$, caused recruitment of tGPH to the cell membrane in all regions of the developing wing (Fig. 3; data not shown). We occasionally observed tGPH recruitment to the cell membrane in response to Ras ${ }^{\mathrm{V} 12 \mathrm{~S} 35}$ expression, but at much lower levels than for Ras ${ }^{\mathrm{V} 12}$ or $\operatorname{Ras}^{\mathrm{V} 12 \mathrm{G} 37}$ (Fig. 3C). Like Ras ${ }^{\mathrm{V} 12}$, Ras ${ }^{\mathrm{V} 12 \mathrm{G} 37}$-dependent recruitment of tGPH was restricted to the apical region of the cell membrane (data not shown). Thus, at the sensitivity thresholds of our assays, Raf ${ }^{\mathrm{GOF}}$ specifically activates MAPK but not dPI3K signaling, Ras ${ }^{\mathrm{V} 12 \mathrm{~S} 35}$ primarily activates MAPK, and Ras ${ }^{\mathrm{V} 12 \mathrm{G} 37}$ specifically activates dPI3K signaling but not MAPK. Expression of Ras ${ }^{\mathrm{V} 12 \mathrm{C} 40}$ had no detectable effect on either MAPK activity or dPI3K signaling (data not shown).

Ras $^{V 12}$ effector loop mutants that activate Raf or dPI3K signaling induce growth and $G_{1} / S$ progression

To test whether Ras ${ }^{\mathrm{V} 12}$ promotes growth and $\mathrm{G}_{1} / \mathrm{S}$ progression via MAPK or $\mathrm{dPI} 3 \mathrm{~K}$ signaling, we generated 

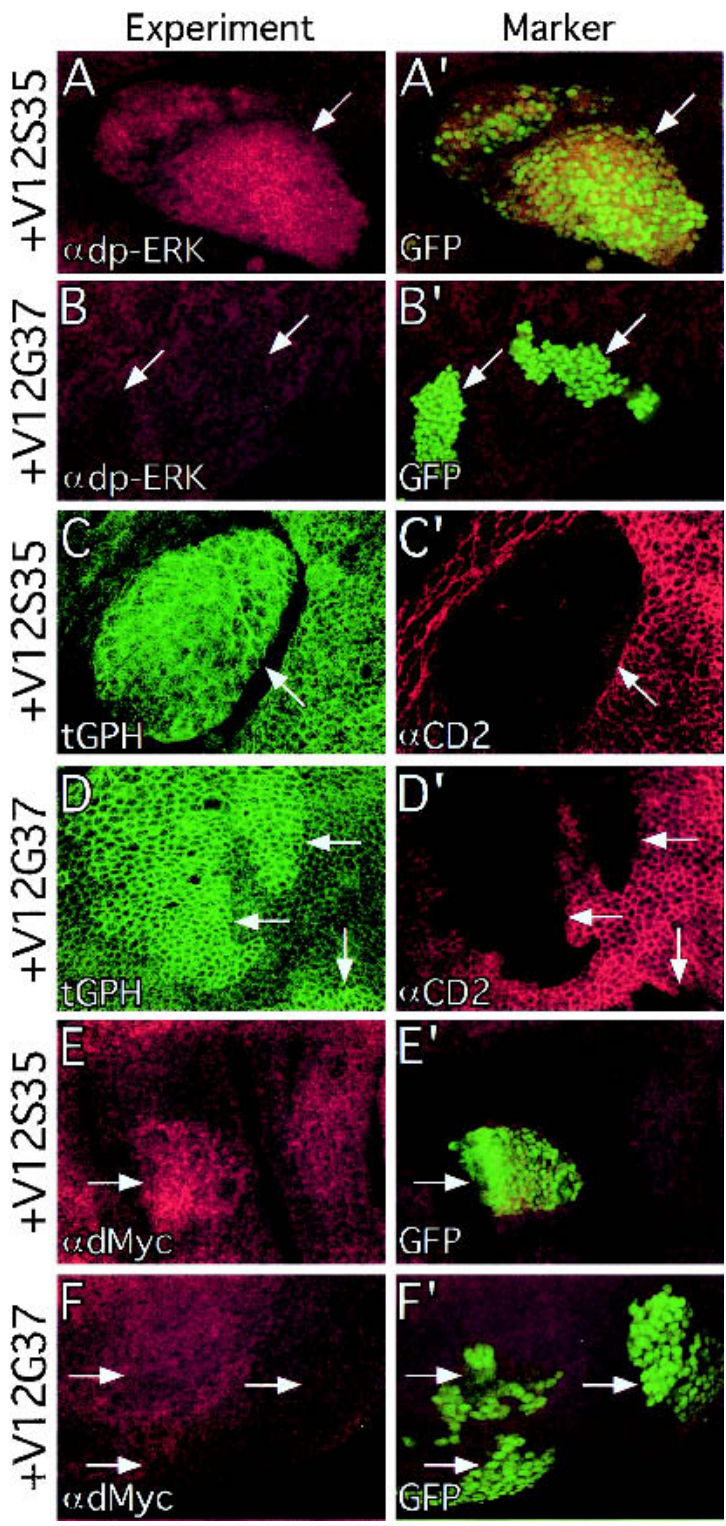

Figure 3. Ras effector loop mutants activate different effector pathways. $(A, B) \mathrm{Flp} / \mathrm{Gal} 4$ clones (marked with GFP in $\left.A^{\prime}, B^{\prime}\right)$ expressing Ras ${ }^{\mathrm{V} 12 \mathrm{~S} 35}$ have increased dp-ERK staining $(A)$, whereas clones expressing Ras ${ }^{\mathrm{V} 12 \mathrm{G} 37}$ do not $(B)$. $(C, D)$ Flp/Gal4 clones (marked by loss of CD2 in $C^{\prime}, D^{\prime}$ ) expressing Ras ${ }^{\mathrm{V} 12 \mathrm{G} 37}$ have increased membrane-associated tGPH $(D)$, whereas clones expressing Ras ${ }^{\mathrm{V} 12 \mathrm{~S} 35}$ do not $(C)$. $(E, F) \mathrm{Flp} / \mathrm{Gal} 4$ clones (marked with GFP in $\left.E^{\prime}, F^{\prime}\right)$ expressing Ras ${ }^{\mathrm{v} 12 \mathrm{~s} 35}$ have increased $\mathrm{dMyc}$ protein levels $(E)$, whereas clones expressing Ras ${ }^{\mathrm{V} 12 \mathrm{G} 37}$ do not $(F)$. Magnification: $A, B, E, F, 40 \times ; C, D, 100 \times$.

GFP-marked clones of cells expressing the Ras ${ }^{\mathrm{V} 12}$ effector loop mutant transgenes in the developing wing. We then performed flow cytometry and compared transgeneexpressing cells with nonexpressing internal control cells (Neufeld et al. 1998). This technique provides forward scatter data, which gives a relative measure of cell size, as well as cell cycle phasing data, which indicates the proportion of cells in the $G_{1}, S$, and $G_{2}$ phases of the cell cycle. We also assayed the effects of the Ras ${ }^{\mathrm{V} 12}$ ef- fector loop mutant transgenes on clonal growth by measuring clone areas. Like $\mathrm{Ras}^{\mathrm{V} 12}$, expression of Ras ${ }^{\mathrm{V} 12 \mathrm{~S} 35}$ Ras $^{\mathrm{V} 12 \mathrm{G} 37}$, or Raf ${ }^{\mathrm{GOF}}$ truncated $\mathrm{G}_{1}$ (Fig. 4A, right), increased cell sizes (Fig, 4A, left), and increased clone areas (Fig. 4B). Because clones expressing Ras ${ }^{\mathrm{V} 12}$, Raf ${ }^{\mathrm{GOF}}$, or Ras $^{\mathrm{V} 12 \mathrm{~S} 35}$ bulge out of the apical surface of the epithelium (see below), two-dimensional area measurements are underestimates of the amount of clonal growth produced. In fact, expression of Ras ${ }^{\mathrm{V} 12 \mathrm{G} 37}$, which does not cause apical bulging, showed a greater increase in twodimensional clone areas (Fig. 4B) and likely provides the most accurate measure of clonal growth rates resulting from ectopic Ras signaling. Thus, the Ras ${ }^{\mathrm{V} 12 \mathrm{~S} 35}$ and $\mathrm{Ras}^{\mathrm{V} 12 \mathrm{G} 37}$ effector loop mutants can both drive growth and $G_{1} / S$ progression to a similar extent as Ras ${ }^{\mathrm{V} 12}$. In contrast, expression of Drosophila Ras ${ }^{\mathrm{V} 12 \mathrm{C} 40}$ had little effect in these assays (Fig. 4A,B). We also expressed an activated form of Drosophila Ral ( $\left.\mathrm{dRal}^{20 \mathrm{~V}}\right)$, a putative Ras target via RalGDS in mammals, that has been implicated in regulating morphogenesis but not growth in Drosophila (Sawamoto et al. 1999). Expression of $\mathrm{dRal}^{2 \mathrm{OV}}$ caused a decrease in cell size without affecting cell cycle phasing (data not shown), suggesting that Drosophila Ras does not promote growth or cell cycle progression via dRal.

\section{Ras increases dMyc levels via the Raf/MAPK pathway}

We next asked which effector pathway is responsible for the $\mathrm{Ras}^{\mathrm{V} 12}$-mediated increase in $\mathrm{dMyc}$ protein levels. Staining with a dMyc-specific antibody revealed that expression of Ras ${ }^{\mathrm{V} 12 \mathrm{~S} 35}$ or Raf ${ }^{\mathrm{GOF}}$ increased dMyc levels, whereas expression of Ras ${ }^{\mathrm{V} 12 \mathrm{G} 37}$ did not (Fig. 3E,F; data not shown). This was observed in all regions of the wing disc, although it was more difficult to detect in regions containing high levels of endogenous $\mathrm{dMyc}$, such as the wing pouch (see below). Thus, Ras ${ }^{\mathrm{V} 12}$ regulates $\mathrm{dMyc}$ levels via the Raf/MAPK pathway and not via dPI3K signaling. The ability of Ras ${ }^{\mathrm{V} 12}$ to affect dMyc and dPI3K signaling via separate pathways suggests that $\mathrm{dMyc}$ and dPI3K may not regulate each other. Accordingly, overexpression of dMyc had no effect on tGPH localization (Fig. $5 \mathrm{~A}$ ) and overexpression of dPI3K had no effect on dMyc levels (Fig. 5B). Thus, Ras ${ }^{\mathrm{V} 12}$ is capable of activating two growth-promoting pathways, but these pathways are incapable of activating each other.

Ras is required to maintain normal levels of dMyc protein but not dPI3K signaling

Having shown that activated variants of Ras can increase dMyc protein levels and activate dPI3K signaling, we next examined whether endogenous Ras does so during normal development. Ras signaling is strongly activated in developing vein cells at the end of larval development, as determined by use of an antibody specific for the activated form of MAPK (Gabay et al. 1997; Guichard et al. 1999; Martin-Blanco et al. 1999). This pattern of activity is maintained until $\sim 30 \mathrm{~h}$ after pupation, at which point Ras activity is down-regulated in vein cells and up-regu- 

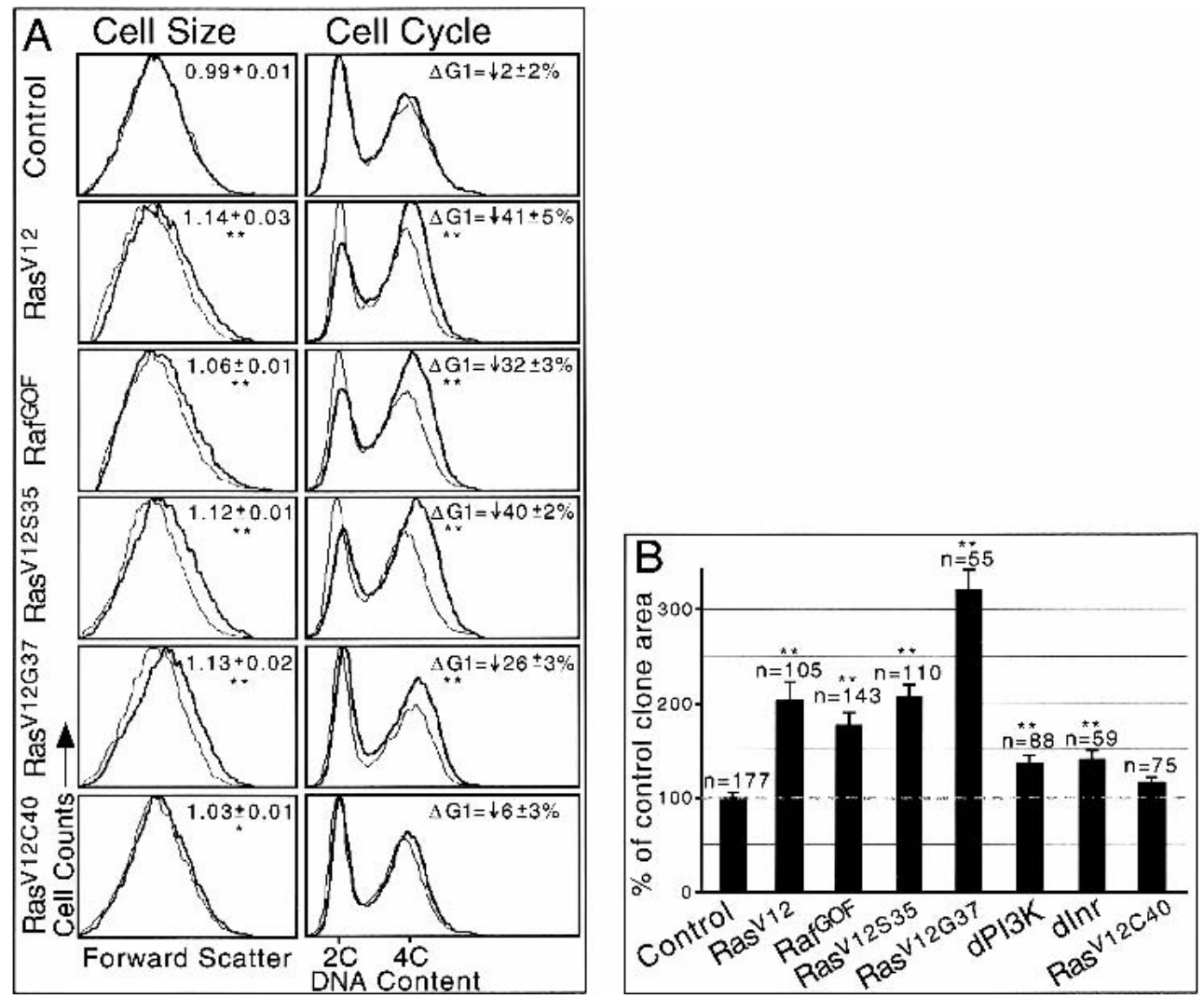

Figure 4. Ras effector loop mutants increase cell size, promote $G_{1} / S$ progression, and increase clonal growth. $(A)$ Flow cytometry. Dark and light traces represent $\mathrm{GFP}^{+}$(experimental) and $\mathrm{GFP}^{-}$(control) cells, respectively. Each trace is normalized to fit the graph as the numbers of $\mathrm{GFP}^{+}$and $\mathrm{GFP}^{-}$cells analyzed for each sample were not exactly equal. Data shown are from an experimental set performed in parallel. Values significantly different from control are indicated $\left({ }^{\star}, P<0.05 ;^{\star \star}, P<0.01\right)$. (Left) Cell size. Forward scatter data, which gives a relative measure of cell size, shows that expression of Ras ${ }^{\mathrm{V} 12}$, Raf ${ }^{\mathrm{GOF}}$, Ras ${ }^{\mathrm{V} 12 \mathrm{~S} 35}$, or Ras ${ }^{\mathrm{V} 12 \mathrm{G} 37}$ increases cell size. Numbers indicate the mean value of $\left(\mathrm{GFP}^{+}\right.$mean FSC)/(GFP ${ }^{-}$mean FSC) \pm standard error of the mean for six experiments (except for Raf ${ }^{\mathrm{GOF}}$, which was repeated four times). (Right) Cell cycle. DNA content data, which shows the proportion of cells in $\mathrm{G}_{1}(2 \mathrm{C})$ and $\mathrm{G}_{2}$ $(4 \mathrm{C})$, indicates that expression of $\mathrm{Ras}^{\mathrm{V} 12}$, Raf ${ }^{\mathrm{GOF}}$, $\operatorname{Ras}^{\mathrm{V} 12 \mathrm{~S} 35}$, or Ras ${ }^{\mathrm{V} 12 \mathrm{G} 37}$ decreases the proportion of cells in $\mathrm{G}_{1}$. Numbers indicate the mean percentage change of $\mathrm{GFP}^{+}$cells compared with $\mathrm{GFP}^{-}$cells in the proportion of cells in $\mathrm{G}_{1}\left(\Delta \mathrm{G}_{1}\right) \pm$ standard error of the mean for six experiments (except for Raf ${ }^{\mathrm{GOF}}$, which was repeated four times). (B) Median areas of Flp/Gal4 clones expressing various transgenes are shown. Expression of any transgene except Ras ${ }^{\mathrm{V} 12 \mathrm{C} 40}$ significantly increased clone areas relative to control clones expressing GFP alone. Clones were induced at $48 \mathrm{~h}$ after egg deposition (AED; except for dInr, which was induced at $72 \mathrm{~h}$ AED) and analyzed at $120 \mathrm{~h}$ AED. $n$, number of clones measured. Error bars, standard error of the mean; ${ }^{\star \star}, P<0.01$ vs. control. Note that larvae overexpressing dPI3K or dInr under these conditions are developmentally delayed, and as a result the clone areas measured in this experiment underestimate dPI3K-and dInr-dependent clonal growth. Overexpression of dMyc also greatly increases clonal growth rates (Johnston et al. 1999).

lated in intervein regions. Genetic data suggests that Ras/MAPK signaling is also active at low levels throughout the tissue (Diaz-Benjumea and Hafen 1994; Prober and Edgar 2000; Halfar et al. 2001). High levels of dmyc mRNA and protein are present in the developing wing pouch, except for several rows of cells along the dorsalventral boundary in which $d m y c$ expression is repressed by Wingless (Supplemental Fig. 3A in Supplementary Material at http://www.genesdev.org; Johnston et al. 1999|. High dMyc protein levels are also present in the notum, and low levels are observed throughout the rest of the tissue. Thus, dMyc appears to be expressed ubiquitously at low levels, with higher levels present in specific regions. In contrast, dPI3K-signaling levels, assayed using tGPH localization, appear uniform throughout the wing during larval and pupal development (Supplemental Fig. 4C in Supplementary Material at http://www. genesdev.org; data not shown). Whereas patterns of dMyc expression and dPI3K activity do not coincide with those of high MAPK activity, we reasoned that the ubiquitous low levels of Ras activity may play a role in regulating dMyc protein levels and dPI3K signaling.

To test whether this is the case, we used FLP/FRTmediated mitotic recombination to generate ras mutant clones $\left(\mathrm{ras}^{-/-}\right)$using the $\mathrm{ras}^{\mathrm{c} 40 \mathrm{~b}}$ allele, in which the entire ras ORF is deleted (Schnorr and Berg 1996). We quantified the requirement for ras to maintain normal dMyc protein levels by staining wing discs with a dMyc-specific antibody and comparing pixel intensities in neighboring regions inside and outside of $\mathrm{ras}^{-/-}$clones (see 

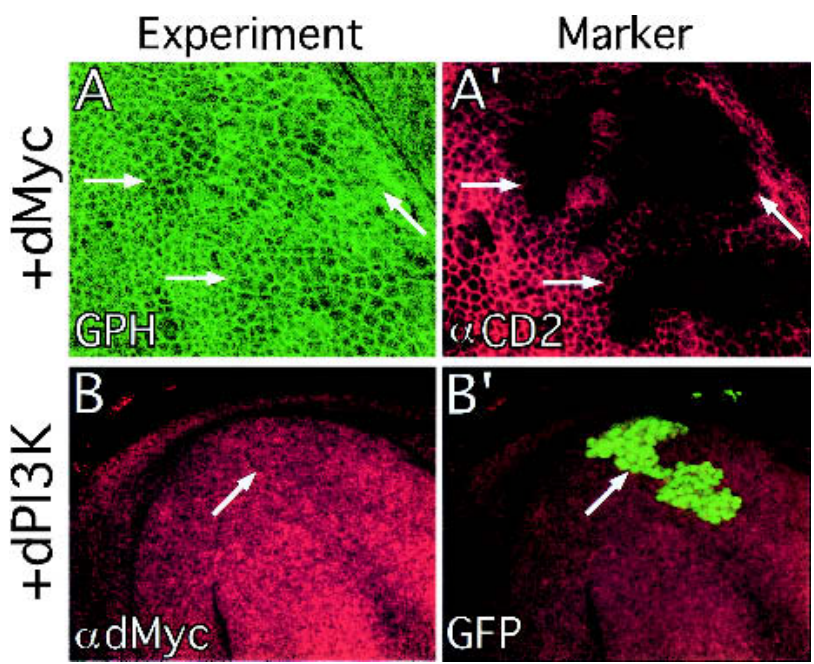

Figure 5. Overexpressed $\mathrm{dMyc}$ and $\mathrm{dPI} 3 \mathrm{~K}$ do not affect each other. $(A)$ Clones of cells overexpressing $\mathrm{dMyc}$ (marked by loss of CD2 in $\left.A^{\prime}\right)$ have normal tGPH localization. $(B)$ Clones of cells overexpressing dPI3K (marked with GFP in $B^{\prime}$ ) have normal dMyc protein levels. Magnification: $A, 100 \times ; B$ 40x.

Materials and Methods). We found dMyc antibody staining intensity to be significantly lower in $\mathrm{ras}^{-/}$cells in all areas of the developing wing, regardless of endogenous dMyc protein levels, although the effect was modest (Fig. $6 \mathrm{~A}, \mathrm{~B})$. Thus, Ras is required to maintain normal dMyc protein levels throughout the developing wing. In contrast, $\mathrm{ras}^{-/-}$clones had no detectable effect on tGPH intensity or localization (Fig. 6C), suggesting that Ras is not required to maintain normal $\mathrm{PIP}_{3}$ levels, and thus levels of dPI3K signaling.

\section{Ras affects cell fate and cell adhesion via} the Raf/MAPK pathway

Ras signaling regulates cell identities in developing imaginal tissues (Rommel and Hafen 1998). To determine which effector pathway is utilized, we examined the abilities of the Ras ${ }^{\mathrm{V} 12}$ effector loop mutants to affect cell differentiation and cell affinity, two aspects of cell identity. Ras signaling promotes specification of photoreceptor neurons in cells posterior to the morphogenetic furrow in the developing eye, which express the neuronspecific protein Elav. We found that transgenes that activated Raf/MAPK signaling $\left(\mathrm{Ras}^{\mathrm{V} 12}\right.$, Raf ${ }^{\mathrm{GOF}}$, and $\mathrm{Ras}^{\mathrm{V} 12 \mathrm{~S} 35}$ ) induced precocious Elav expression anterior to the morphogenetic furrow, whereas transgenes that activated dPI3K signaling (Ras ${ }^{\mathrm{V} 12 \mathrm{G} 37}$ and dPI3K) did not (Fig. 7). Overexpressed dMyc and Ras ${ }^{\mathrm{V} 12 \mathrm{C} 40}$ also had no effect on Elav expression (Fig. 7; data not shown).

Clones expressing $\mathrm{Ras}^{\mathrm{V} 12}$ are round with smooth borders (Prober and Edgar 2000), suggesting that they have altered cell affinities, and, as a result, minimize contact with neighboring wild-type cells. These clones also often generate ectopic folds in the tissue and bulge out of the apical surface of the epithelium. This contrasts with control clones expressing GFP alone, which are ran- domly shaped and intermingle with neighboring cells. To determine which Ras effector pathway is responsible for this phenotype, we measured clone roundness by comparing the areas of clones with their circumferences, using a formula that produces a value of 1 for a perfect circle (see Materials and Methods). Clones expressing $\operatorname{Ras}^{\mathrm{V} 12}$, Raf ${ }^{\mathrm{GOF}}$, or Ras ${ }^{\mathrm{V} 12 \mathrm{~S} 35}$ were all visibly round and had values of $\sim 0.7$, whereas control clones expressing GFP alone and clones expressing $\mathrm{Ras}^{\mathrm{V} 12 \mathrm{C} 40}$ had significantly lower values of $\sim 0.35$ (Fig. 8). Clones expressing either Ras ${ }^{\mathrm{V} 12 \mathrm{G} 37}$, dPI3K, or dMyc were not visibly round, did not generate ectopic folds, and did not bulge out of the epithelium. These clones had values of $\sim 0.45$ (Fig. 8).
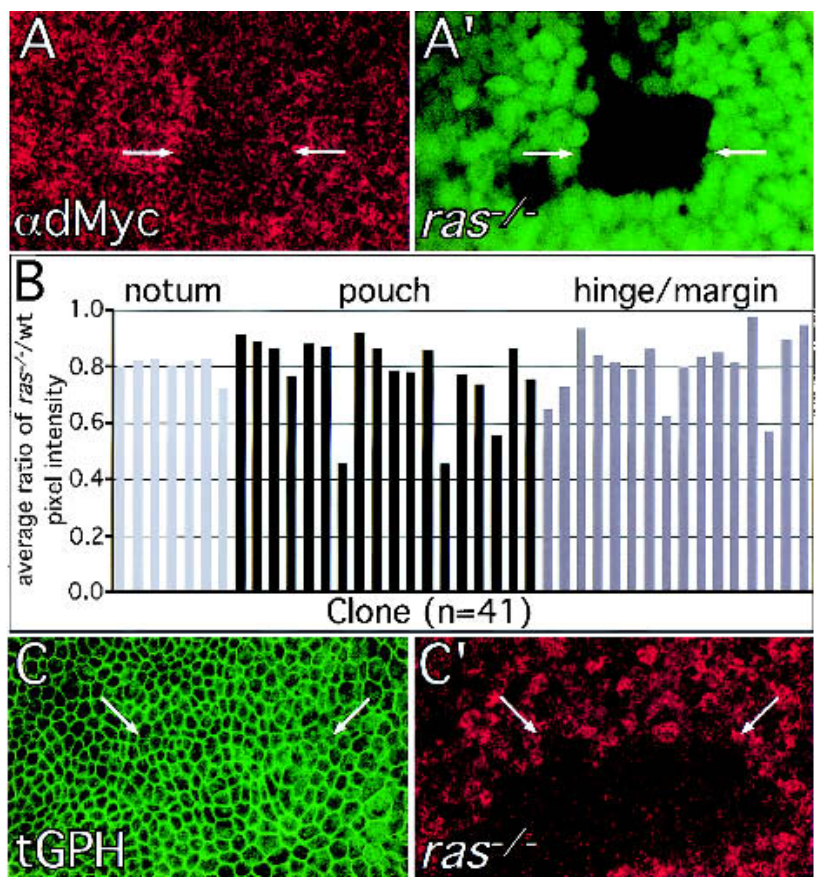

Figure 6. Endogenous Ras is required to maintain normal levels of dMyc protein but not dPI3K signaling. The FLP/FRT technique was used to generate $\mathrm{ras}^{-/-}$clones in $\mathrm{ras}^{+/}$tissues. $(A)$ $\mathrm{ras}^{-/-}$cells (marked by loss of GFP in $A^{\prime}$ ) have reduced levels of dMyc protein. Genotype: hs-FLP ${ }^{122}$; UAS-P35/en-Gal4; FRT (82B) $\mathrm{ras}^{\mathrm{c40b}} /$ FRT (82B) Ub-GFP. (B) Quantitation of dMyc antibody staining intensity in $\mathrm{ras}^{-/-}$clones compared with neighboring $\mathrm{ras}^{+/-}$and $\mathrm{ras}^{+/+}$regions. Ratios of average pixel intensity $\mathrm{ras}^{-/-}$/average pixel intensity $\mathrm{ras}^{+/-}$or $\mathrm{ras}^{+/+}$were calculated for individual clones. To minimize confounding bias due to patterned endogenous dMyc levels, each bar represents the average value of 10-15 ratios for a single clone (see Materials and Methods). Regions within $\mathrm{ras}^{-/-}$clones consistently had lower values than surrounding regions (average $=0.79 \pm 0.02 ; P=2 \times 10^{-6}$ for 41 clones). $\mathrm{dMyc}$ antibody staining intensities in neighboring $\mathrm{ras}^{+/-}$and $\mathrm{ras}^{+/+}$regions were not significantly different (average ratio of $\mathrm{ras}^{+/-} / \mathrm{ras}^{+/+}=0.95 \pm 0.05, P=0.45$ for 11 clones). $\mathrm{ras}^{-/-}$ clones had similar effects on dMyc antibody staining intensities in regions of the wing with high (notum and pouch) and low (hinge/margin) endogenous dMyc levels. $(C) \mathrm{ras}^{-1-}$ cells (marked by loss of the $\pi$ myc marker in $C^{\prime}$ ) have normal tGPH localization and intensity. Genotype: hs-FLP ${ }^{122}$; UAS-P35/tGPH; enGal4; FRT (82B) $\mathrm{ras}^{\mathrm{c} 40 b} /$ FRT (82B) hs- $\pi$ myc. Magnification: $A, B$, $100 \times$. 

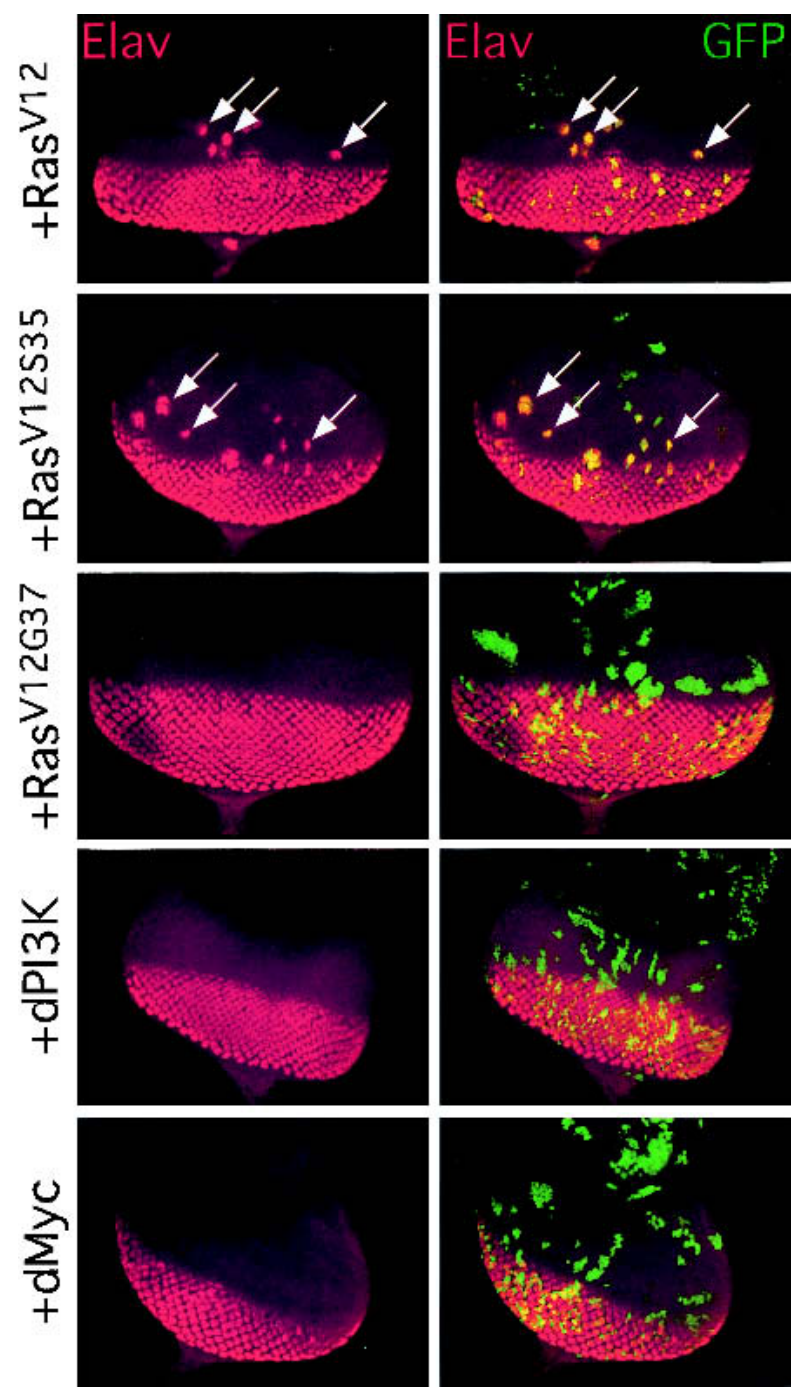

Figure 7. Ras promotes precocious photoreceptor differentiation via Raf/MAPK signaling. Eye discs with Flp/Gal4 clones (marked with GFP at right) expressing various transgenes are shown. Expression of $\mathrm{Ras}^{\mathrm{V} 12}$ or Ras ${ }^{\mathrm{V} 12 \mathrm{~S} 35}$ induces precocious Elav staining (arrows), whereas expression of Ras ${ }^{\mathrm{V} 12 \mathrm{G} 37}$, dPI3K, or dMyc does not. Magnification, 20x.

This small, but significant increase in clone roundness values compared with controls resulted from a more compact arrangement of cells within the clones. These results indicate that the Raf/MAPK pathway is primarily responsible for the effect of Ras ${ }^{\mathrm{V} 12}$ on cell adhesion. Furthermore, the inability of overexpressed dMyc to produce round clones or induce precocious Elav expression shows that regulation of $\mathrm{dMyc}$ levels and cell identity are separate effects of Raf/MAPK signaling. Interestingly, the round clone phenotype of $\mathrm{Ras}^{\mathrm{V} 12}$, $\mathrm{Raf}^{\mathrm{GOF}}$, and Ras $^{\mathrm{V} 12 \mathrm{~S} 35}$ was associated with increased levels and mislocalization of DE-Cadherin/Shotgun (Shg) and $\beta$-catenin/Armadillo (Arm), whereas transgenes that did not produce round clones had no effect on Shg or Arm (D.A. Prober, unpubl.). Shg and Arm mediate intercellular adhesion, suggesting a potential mechanism for the effect of Ras/Raf/MAPK signaling on cell affinity. We therefore conclude that Ras affects cell identities via Raf/MAPK and not via dPI3K.

\section{Lack of cross-talk between dEGFR-and dInr-dependent signaling}

We next assayed cross-talk between the dEGFR/Ras and dInr/dPI3K pathways at the level of the receptors. Expression of an activated form of the Drosophila EGF receptor $\left(\mathrm{dEGFR}^{\lambda \text { top }}\right)$ resulted in elevated levels of MAPK activity (data not shown) and dMyc protein (Supplemental Fig. 5A in Supplementary Material at http://www. genesdev.org) in wing discs, and induces precocious Elav expression in the eye (Dominguez et al. 1998). In contrast, dEGFR ${ }^{\lambda \text { top }}$ had no detectable effect on dPI3K signaling (Supplemental Fig. 5B in Supplementary Material at http://www.genesdev.org). Overexpressed dInr strongly recruited tGPH throughout the cell membrane (Supplemental Fig. 5D in Supplementary Material at http://www.genesdev.org; data not shown), but did not activate MAPK (data not shown), increase dMyc levels (Supplemental Fig. 5C in Supplementary Material at http://www.genesdev.org), or affect Elav expression in the eye (data not shown). Thus, we found no evidence for cross-talk between these pathways at the receptor level.

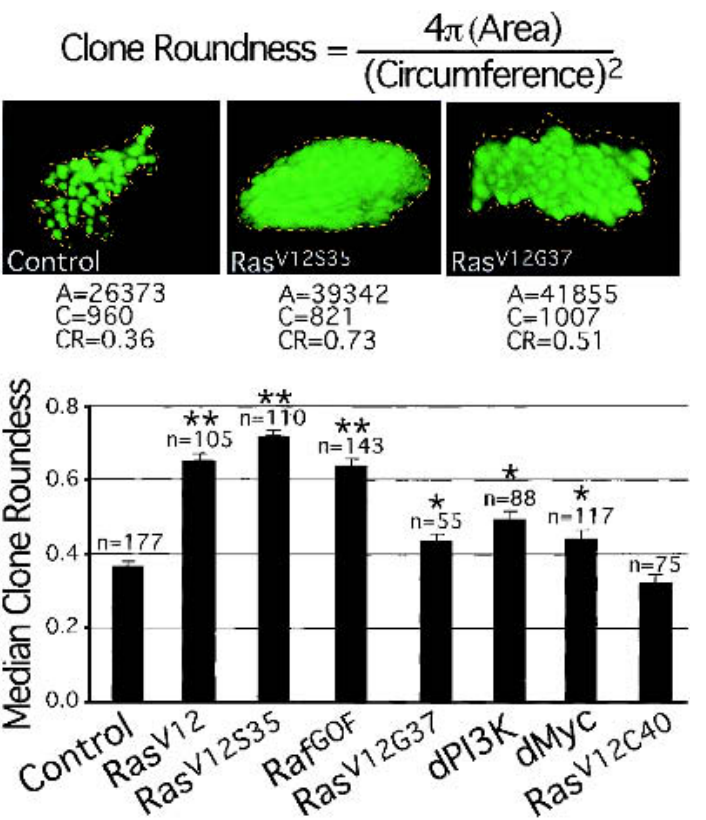

Figure 8. Ras affects clone shape via the Raf/MAPK pathway. Median clone roundness values of Flp/Gal4 clones expressing various transgenes are shown. Expression of any transgene except Ras ${ }^{\mathrm{V} 12 \mathrm{C} 40}$ significantly increases clone roundness relative to control clones expressing GFP alone, although Ras ${ }^{\mathrm{v} 2}$, $\mathrm{Ras}^{\mathrm{V} 12 \mathrm{~S} 35}$, and Raf ${ }^{\mathrm{GOF}}$ have significantly stronger effects than $\mathrm{Ras}^{\mathrm{V} 12 \mathrm{G} 37}$, dPI3K, and dMyc. Representative images and measurements are shown. Clones were induced at $48 \mathrm{~h}$ after egg deposition (AED) and analyzed at $120 \mathrm{~h} \mathrm{AED.} \mathrm{A,} \mathrm{clone} \mathrm{area;} \mathrm{C,}$ clone circumference; $\mathrm{CR}$, clone roundness; $n$, number of clones measured. Error bars: standard error of the mean; ${ }^{\star}, P<0.001$ vs. control; $^{\star \star}{ }^{\star}, P \ll 0.001$ vs. control. 


\section{Discussion}

Recent studies using the developing Drosophila wing have shown that Ras, $\mathrm{dMyc}$, and $\mathrm{dPI} 3 \mathrm{~K}$ regulate rates of cellular growth (i.e., mass accumulation) and progression through the $G_{1} / S$ transition of the cell cycle without affecting overall rates of cell division (Johnston et al. 1999; Weinkove et al. 1999; Prober and Edgar 2000). These studies concur with experiments in mice showing that Ras, Myc, and PI3K promote cell growth without affecting rates of cell division (Iritani and Eisenman 1999; Heumann et al. 2000; Kim et al. 2000; Shioi et al. 2000). Here, we show that an activated form of Drosophila Ras $\left(\operatorname{Ras}^{\mathrm{V} 12}\right)$ is capable of increasing dMyc protein levels as well as levels of dPI3K signaling, suggesting that Ras ${ }^{\mathrm{V} 12}$ drives growth and $\mathrm{G}_{1} / \mathrm{S}$ progression via both of these mechanisms. We also use Ras ${ }^{\mathrm{V} 12}$ effector loop mutants to show that Ras ${ }^{\mathrm{V} 12}$ affects dMyc and dPI3K signaling via separate pathways, and we show that overexpressed $\mathrm{dMyc}$ and $\mathrm{dPI} 3 \mathrm{~K}$ do not cross-regulate each other. Thus, we have established a hierarchy for these growth-regulatory proteins (Fig. 9).

Ras is required to maintain normal dMyc levels during development

Wing disc cells lacking ras had reduced levels of dMyc protein, indicating that Ras is required to maintain nor-

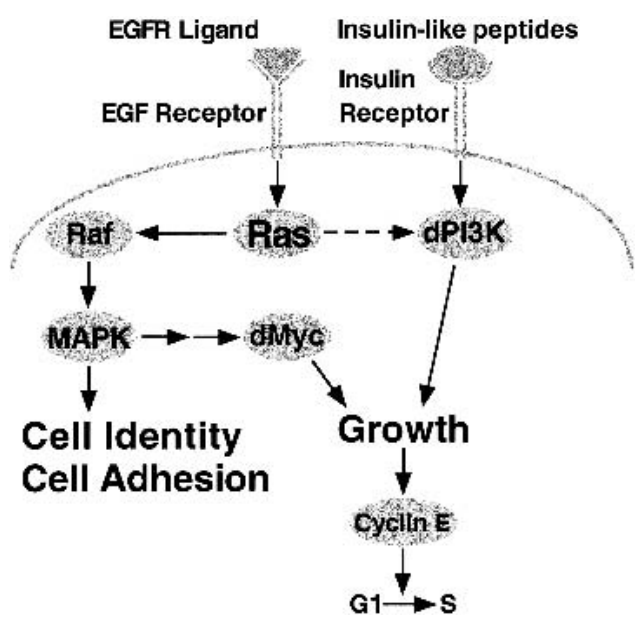

Figure 9. Model for interactions between Ras, $\mathrm{dMyc}$, and dPI3K in the developing Drosophila wing. Ectopic expression of $\mathrm{Ras}^{\mathrm{V} 12}$ drives cell growth via at least two genetically separable pathways. Ras ${ }^{\mathrm{V} 12}$ activates Raf/MAPK signaling, which increases levels of dMyc protein. Ras ${ }^{\mathrm{V} 12}$ also independently activates dPI3K signaling. The resulting increased rate of cell growth increases cyclin $\mathrm{E}$ protein levels, thereby promoting G1/S progression (Prober and Edgar 2000). Ras is normally activated by the binding of ligands to the EGF receptor, and is required to maintain normal levels of dMyc protein but not dPI3K signaling (dashed arrow). dPI3K is likely normally regulated by the binding of insulin-like peptides to the Insulin receptor. $\mathrm{Ras}^{\mathrm{V} 12}$ also affects cell identity and adhesion via Raf/MAPK signaling. Arrows indicate genetic interactions and do not imply direct molecular interactions. mal dMyc protein levels during wing development. $\mathrm{ras}^{-/-}$cells contained significant levels of dMyc protein, however, indicating that Ras is not absolutely necessary for dMyc expression, and suggesting that reduced dMyc levels may not fully explain the growth deficit of $\mathrm{ras}^{-/-}$ cells. However, we found that dMyc antibody staining intensity was $\sim 40 \%$ lower for $d m y c^{P O}$ or $d m y c^{P 1}$ homozygotes than for $d m y c^{P O}$ heterozygotes in regions of the wing disc that normally contain high dMyc levels (i.e., wing pouch and notum; Supplemental Table 1 in Supplementary Material at http://www.genesdev.org). Because $d m y c^{P O / P O}$ clones have severely reduced growth rates (Johnston et al. 1999), it seems reasonable to expect that the $\sim 20 \%$ reduction of dMyc levels in $\mathrm{ras}^{-/-}$clones will also reduce growth rates. We showed previously that Ras $^{\mathrm{V} 12}$ increases dMyc levels post-transcriptionally (Prober and Edgar 2000), and studies in mammalian cell culture showed that Ras ${ }^{\mathrm{V} 12}$ stabilizes Myc protein (Sears et al. 2000). Therefore, it is likely that $\mathrm{ras}^{-/-}$cells still transcribe dmyc mRNA, but that following translation, $\mathrm{dMyc}$ protein is less stable. What other mechanisms may regulate dMyc levels? Wingless $(\mathrm{Wg})$ signaling represses $d m y c$ expression along the dorsal-ventral boundary of the developing wing (Johnston et al. 1999). In addition, expression of an activated version of the Decapentaplegic (Dpp) receptor Thickveins $\left(\mathrm{Tkv}^{\mathrm{Q} 238 \mathrm{D}}\right)$ can increase levels of dMyc protein in the wing, whereas loss of this same receptor suppresses dMyc levels (C. Martin-Castellanos and B.A. Edgar, unpubl.). Thus, Ras signaling may be one of many inputs affecting dMyc expression in the wing. Ras may stabilize the low levels of dMyc protein observed throughout the developing wing and/or refine the patterned $d m y c$ expression regulated by other signals. The complex regulation of dMyc expression in vivo may account for the lack of a clear correspondence between patterns of high endogenous Ras activity and dMyc expression (Supplemental Fig. 4 in Supplemental Materials at http://www.genesdev.org).

\section{Ras is not required to maintain normal} dPI3K-signaling levels

We found that overexpressed Drosophila Ras ${ }^{\mathrm{V} 12}$ recruited the tGPH reporter to the cell membrane, suggesting that $\mathrm{Ras}^{\mathrm{V} 12}$ activates dPI3K signaling, and thereby increases $\mathrm{PIP}_{3}$ levels, in the developing wing. We infer that Drosophila Ras ${ }^{\mathrm{V} 12}$ directly activates dPI3K, because mammalian studies have shown that Ras ${ }^{\mathrm{V} 12}$ can directly bind and activate PI3K (Rodriguez-Viciana et al. 1994. Pacold et al. 2000). Alternatively, Drosophila Ras ${ }^{\mathrm{V} 12}$ may activate dPI3K signaling via other mechanisms, such as by inhibiting the lipid phosphatase dPTEN. This possibility seems less likely, however, as direct interactions between Ras and PTEN have not been described. Contradicting the generally accepted idea that PI3K is normally an effector of Ras signaling (Rommel and Hafen 1998), we found that localization of the PI3K reporter tGPH was not detectably affected in $\mathrm{ras}^{-/-}$cells. Although our observations using the $\mathrm{tGPH}$ reporter were not quantitative, and small effects could have been 
missed, these results nevertheless indicate that Ras does not normally play a major role in regulating $\mathrm{dPI} 3 \mathrm{~K}$ in the developing wing. Consistent with this hypothesis, expression of an activated form of $\operatorname{dEGFR}\left(\mathrm{dEGFR}^{\lambda \text { top}}\right)$ had no effect on dPI3K signaling (Supplemental Fig. 5B in Supplementary Material at http://www.genesdev.org). Because the ability of dEGFR ${ }^{\lambda \text { top }}$ to activate downstream pathways is limited by the amount of endogenous Ras, this result suggests that higher levels of Ras activity than can be generated in wild-type cells are required to activate dPI3K.

An alternative explanation for the discrepancy between the involvement of Drosophila and mammalian Ras in regulating PI3K signaling may relate to the evolution of ras genes. The Drosophila and C. elegans Ras homologs are more homologous to mammalian K-Ras than to H- or N-Ras (Neuman-Silberberg et al. 1984; Han and Sternberg 1990), suggesting that K-Ras may have an older, more general function than the other mammalian ras genes. In support of this idea, $\mathrm{H}$ - and N-Ras are dispensable, whereas K-Ras is essential, for normal mouse development (Umanoff et al. 1995; Johnson et al. 1997; Koera et al. 1997). It is also interesting to note that overexpressed K-Ras preferentially activates Raf over PI3K, whereas the opposite is true for H-Ras (Yan et al. 1998). Thus, K-Ras may play a more fundamental role in developmental processes dependent on Raf, but independent of PI3K, whereas $\mathrm{H}$ - and $\mathrm{N}$-Ras may have evolved to perform less critical functions in which they regulate PI3K.

\section{Regulation of dPI3K signaling in the developing wing}

Using the tGPH reporter, we found that levels of $\mathrm{dPI} 3 \mathrm{~K}$ signaling are not patterned but rather are uniform throughout wing development (Supplemental Fig. 4 in Supplementary Material at http://www.genesdev.org). It is therefore unlikely that $\mathrm{dPI} 3 \mathrm{~K}$ signaling is regulated by localized patterning signals such as the morphogens Vein, Dpp, and Wg, which are secreted from the notum, anterior-posterior boundary, and dorsal-ventral boundary of the wing, respectively, and are thought to pattern growth and cell proliferation of the wing. Furthermore, cell-autonomous activation of Dpp signaling using an activated form of its receptor $\left(\mathrm{TkV}^{\mathrm{Q} 253 \mathrm{D}}\right)$, which is a potent growth driver in the wing (Martin-Castellanos and Edgar 2002), has no effect on tGPH localization (C. Martin-Castellanos and B.A. Edgar, unpubl.). It may be that Dpp and Wg regulate cell growth rates by affecting the ability of cells to respond to ubiquitous dPI3K-dependent growth signals. They may do so by regulating the expression or activity of signaling proteins or transcription factors required for transducing dPI3K-dependent signals.

The tGPH reporter revealed that the polarized epithelial cells of Drosophila wing discs contain dense regions of tGPH colocalized with Armadillo at the apical region of the cell membrane, with lower tGPH levels present throughout the basolateral cell membrane (Fig. 2A). This does not simply reflect an apical accumulation of membrane microdomains enriched in $\mathrm{PIP}_{3}$ in polarized cells, because inhibiting $\mathrm{dPI} 3 \mathrm{~K}$ activity by expressing $\Delta \mathrm{p} 60$ dramatically reduced apical tGPH fluorescence (Figs. 1F, 2D). In contrast, tGPH is uniformly localized throughout the cell membranes of unpolarized Drosophila fat body cells in vivo and Drosophila S2 cells in culture (Britton et al. 2002). Similarly, mammalian PI3K is uniformly active throughout the cell membrane of cultured HEK 293 cells (Gray et al. 1999). Thus, the dynamics of dPI3K signaling are dependent on the cellular context, which is likely disturbed when tissues are dissociated into single cells that are studied in culture. This process may allow signaling interactions not normally occurring in vivo ( $\mathrm{Si}$ mons and Toomre 2000). In support of this idea, overexpression of the Drosophila Insulin receptor homolog (dInr) did not activate MAPK in the developing wing (Table 1) or affect Ras-mediated cell fate specification in the developing eye (Table 1; Brogiolo et al. 2001), whereas addition of insulin to cultured Drosophila or mammalian cells does activate Ras/MAPK signaling (Biggs and Zipursky 1992; Saltiel and Kahn 2001). Alternatively, our failure to detect activation of Ras signaling in response to overexpressed dInr may reflect a cell-type

Table 1. Summary of effects resulting from expression of UAS-regulated transgenes

\begin{tabular}{|c|c|c|c|c|c|c|c|c|}
\hline UAS-transgene & $\begin{array}{l}\text { Increased } \\
\text { cell size }\end{array}$ & $\begin{array}{l}\text { Truncated } \\
\mathrm{G}_{1}\end{array}$ & $\begin{array}{l}\text { Increased } \\
\text { clone area }\end{array}$ & $\begin{array}{l}\text { Active } \\
\text { MAPK }\end{array}$ & $\begin{array}{c}\text { Increased } \\
\text { dMyc }\end{array}$ & $\begin{array}{l}\text { Active } \\
\text { dPI3K }\end{array}$ & $\begin{array}{l}\text { Round } \\
\text { clones }\end{array}$ & $\begin{array}{c}\text { Ectopic } \\
\text { elav }\end{array}$ \\
\hline $\operatorname{Ras}^{\mathrm{V} 12}$ & + & + & + & + & + & + & + & + \\
\hline Raf $^{\text {GOF }}$ (MAPK-specific) & + & + & + & + & + & - & + & + \\
\hline $\operatorname{Ras}^{\mathrm{V} 12 \mathrm{G} 37}$ (dPI3K-specific) & + & + & + & - & - & + & \pm & - \\
\hline dPI3K & + & + & + & - & - & + & \pm & - \\
\hline dMyc & + & + & + & - & + & - & \pm & - \\
\hline $\mathrm{dEGFR}^{\lambda \text { top }}$ & $+{ }^{\mathrm{b}}$ & $++^{b}$ & N.D. & + & + & - & + & $+^{\mathrm{c}}$ \\
\hline $\operatorname{Ras}^{\mathrm{V} 12 \mathrm{C} 40}$ & - & - & - & - & - & - & - & - \\
\hline
\end{tabular}

${ }^{a}$ A. de la Cruz and B.A. Edgar, unpubl.

${ }^{b}$ K. Plow and B.A. Edgar, unpubl.

${ }^{\mathrm{c}}$ Dominguez et al. (1998).

N.D., Not done. 
specificity for this interaction or insufficient sensitivity of our assays. It will therefore be interesting to compare the subcellular localization of PI3K signaling complexes in cultured mammalian cells with the tissues from which they are derived.

dPI3K signaling is thought to be regulated by a family of secreted Drosophila insulin-like peptides (dilps) that bind and activate dInr (Brogiolo et al. 2001; Rulifson et al. 2002). Brogiolo et al. (2001) reported that dilp2 is ubiquitously expressed in imaginal tissues, whereas dilp2 and other dilp family members are expressed in a variety of larval tissues including the gut and neurosecretory cells in the brain. dilp2 that is expressed in imaginal tissues is likely secreted apically into the lumen between cells of the columnar epithelium and the overlying peripodial membrane. This would result in preferential binding of dIlp2 to dInr at the apical region of the cell, which could account for the high levels of apically localized tGPH that we observed (Fig. 2A). Alternatively, apical dPI3K signaling may reflect a local concentration of dPI3K-signaling complexes. Consistent with the latter possibility, Ras ${ }^{\mathrm{V} 12}$ only recruited tGPH to apical regions of the cell membrane. This result suggests that Ras ${ }^{\mathrm{V} 12}$ may require other apically localized factors to activate dPI3K signaling. This possibility is supported by our finding that coexpressed $\Delta \mathrm{p} 60$, which prevents $\mathrm{dPI} 3 \mathrm{~K}$ from interacting with upstream activators, blocked $\mathrm{Ras}^{\mathrm{V} 12}$-mediated activation of $\mathrm{dPI} 3 \mathrm{~K}$ signaling, as it does in mammals (Rodriguez-Viciana et al. 1997). Because mammalian Ras can directly bind the catalytic subunit of PI3K (Rodriguez-Viciana et al. 1994; Pacold et al. 2000), we infer that coexpressed $\Delta$ p60 should not affect the ability of Drosophila Ras to activate dPI3K signaling unless Ras-dependent activation requires other apically localized factors that bind $\Delta \mathrm{p} 60$. These factors may include the Insulin receptor substrate Chico, dInr itself or other receptor tyrosine kinases, G-protein coupled receptors, or components of signaling complexes that are recruited upon activation of these receptors. Several receptor tyrosine kinases, including dEGFR, as well as phosphotyrosine-containing proteins, are concentrated at the apical cell surface (Woods et al. 1997; C. Delorenzo and P. Bryant, pers. comm.), although dInr is distributed throughout the cell membrane (Supplemental Fig. 6A in Supplementary Material at http://www.genesdev.org). The Drosophila homolog of the heterotrimeric G-protein subunit Goi (Schaefer et al. 2001), which presumably transduces signals from a large family of associated receptors, is also concentrated apically in wing disc cells (Supplemental Fig. 6B,C in Supplementary Material at http://www.genesdev.org). This is consistent with the possibility that heterotrimeric G-proteins may regulate dPI3K signaling in Drosophila, as they do in mammals (Vanhaesebroeck et al. 2001).

\section{Implications for cancer}

Much of our understanding of Ras function, and that of most oncogenes, derives from studies in homogenous cell culture systems. These studies have focused prima- rily on cell-autonomous effects of oncogenes rather than upon the roles of interactions among cells within tissues in tumor development. Tissue homeostasis is maintained by a continuous exchange of signals between cells, the extracellular matrix, and the local environment. An important feature of tumor development is escape from this regulation, initially allowing the autonomous growth and proliferation of tumor cells, and eventually resulting in altered adhesion and migration of tumor cells away from their site of origin. The behavior of clones of cells with elevated Raf/MAPK signaling levels in developing Drosophila epithelia is strikingly similar to that of tumor cells within mammalian tissues. These cells have altered adhesive properties and cell identities, and as a result minimize contact with neighboring wild-type cells. In contrast, dPI3K and dMyc do not regulate cell identity or adhesion (Figs. 7, 8). Studies in Drosophila and vertebrates have also suggested that even though both dMyc and dPI3K stimulate growth, they appear to do so via different mechanisms. dPI3K signaling promotes nutrient import and storage (Saltiel and Kahn 2001), whereas dMyc promotes nucleolar growth and protein synthesis (Iritani and Eisenman 1999; Britton, 2000; Coller et al. 2000; Guo et al. 2000; Boon et al. 2001). Thus, the ability of Ras ${ }^{\mathrm{V} 12}$ to up-regulate both of these pathways may generate a more robust and balanced growth response than activation of either dMyc or dPI3K alone. Furthermore, the ability of Ras ${ }^{\mathrm{V} 12}$ to deregulate cell identity and adhesion may underlie the strong synergy between Ras and other growth-promoting oncogenes in vivo (Land et al. 1983; Sinn et al. 1987).

\section{Materials and methods}

\section{Fly strains}

All transgenes are $\mathrm{P}[+]$ in $\mathrm{w}^{-}$strains. hs-FLP ${ }^{122} ;+$; UAS-Ras ${ }^{\mathrm{V} 12}$

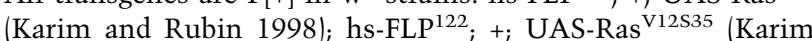

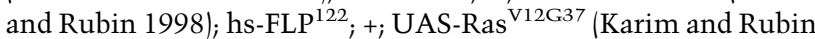

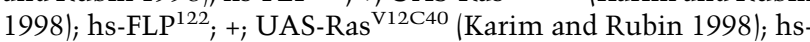
FLP $^{122}$; +; UAS-RafGOF (Brand and Perrimon 1994); hs-FLP ${ }^{122}$; +; UAS-dMyc (Zaffran et al. 1998); hs-FLP ${ }^{122}$; +; UAS-dPI3K (Dp110; Leevers et al. 1996); hs-FLP ${ }^{122}$; +; UAS- $\Delta$ p60 (Weinkove et al. 1999); hs-FLP ${ }^{122}$; +; UAS-dInr (Huang et al. 1999); hsFLP $^{122} ;+$; UAS-dRal ${ }^{20 \mathrm{~V}}$ (Sawamoto et al. 1999); UAS-EGFR ${ }^{\text {גtop }}$ $+;+($ Queenan et al. 1997); w; +; Actin 5c>CD2>Gal4, UASGFP $_{\text {NLS }}$ (Pignoni and Zipursky 1997; Neufeld et al. 1998); w; tGPH, Actin 5c>CD2>Gal4 (Britton et al. 2002); w; UAS-P35; + (Hay et al. 1994); w; +; FRT (82B) $\mathrm{ras}^{\mathrm{c40b} / T M 6 B}$ (Schnorr and Berg 1996); w; +; FRT (82B) M(3)95A Ub-GFP/TM6B (Andersson et al. 1994); w; +; FRT (82B) hs- $\pi \mathrm{myc}^{-} \mathrm{w}_{\text {; hs-FLP }}{ }^{\mathrm{AA}}$; +; and w; en-Gal4; +

\section{Flow cytometry and clonal growth rate analysis}

Clones of cells overexpressing various UAS-regulated transgenes were generated using the Flp/Gal4 method (Struhl and Basler 1993; Pignoni and Zipursky 1997; Neufeld et al. 1998). Larvae were staged from hatching and raised at a density of 50 per vial at $25^{\circ} \mathrm{C}$. For FACS analysis (Neufeld et al. 1998; Prober and Edgar 2000), Flp/Gal4 clones were induced by a 1 -h heat shock at $37^{\circ} \mathrm{C}$ at $72 \mathrm{~h}$ after egg deposition (AED), resulting in 
$\sim 50 \% \mathrm{GFP}^{+}$cells, and wing discs were analyzed at $120 \mathrm{~h} \mathrm{AED}$. Approximately 20,000 $\mathrm{GFP}^{+}$and $\mathrm{GFP}^{-}$cells were analyzed for each genotype in each experiment. For clone area measurements, $~ 5-10$ clones/disc were induced by a 30-min heat shock at $37^{\circ} \mathrm{C}$ at $48 \mathrm{AED}$ and measured at $120 \mathrm{~h}$ AED. Samples were blinded for analysis. Clone areas were measured using the histogram function of Adobe Photoshop. $P$ values were calculated using a two-tailed student's t-test. All samples and controls were tested in parallel.

\section{Clone shape measurements}

Clone shapes were measured using the formula $4 \pi \mathrm{A} / \mathrm{L}^{2}$, in which $\mathrm{A}=$ clone area and $\mathrm{L}=$ clone circumference (Lawrence et al. 1999). By use of this formula, a perfect circle has a value of 1 and more irregular shapes have values $<1$. Samples were blinded for analysis, which was performed using NIH Image. $P$ values were calculated using a two-tailed student's t-test.

\section{Mitotic recombination}

Mitotic recombination was induced using the FLP/FRT method (Xu and Rubin 1993) by a 45-min heat shock at 48 h AED, and wing discs were analyzed at $120 \mathrm{~h}$ AED. Larvae were heat shocked for $1 \mathrm{~h}$ immediately prior to dissection when the $\pi$ myc clonal marker was used. en-Gal4 was used to express P35 in posterior wing compartments to increase the size of $\mathrm{ras}^{\mathrm{c} 40 \mathrm{~b}}$ clones (Prober and Edgar 2000).

\section{Immunocytochemistry}

Imaginal discs were fixed in $4 \%$ paraformaldehyde/PBS for 20 min at $37^{\circ} \mathrm{C}$. All washes and antibody incubations were performed in $0.1 \%$ Tween-20/PBS. Primary antibodies used were mouse anti-dMyc (P4C4 B10, Prober and Edgar 2000, undiluted), mouse anti-CD2 (Serotec, 1:500), mouse anti-Armadillo (N2 7A1, Developmental Studies Hybridoma Bank, 1:100), mouse anti-dpERK (Sigma, 1:200), mouse anti-c-Myc (Calbiochem, 1: 50), and rat anti-Elav (DSHB, 1:30). Alexa 488, 568, and 660conjugated secondary antibodies (Molecular Probes) were used at 1:1500. Tissues were permeabilized for $30 \mathrm{~min}$ in $0.3 \%$ Triton $\mathrm{X}-100 / \mathrm{PBS}$ prior to incubation with dMyc- and Elav-specific antibodies. Discs were mounted in Fluoroguard (Bio-Rad) and imaged on a Leica TCS SP confocal microscope. Cross-section images were obtained using double-stick tape as a spacer between the slide and coverslip and the XZ function of the Leica software.

\section{dMyc antibody quantitation}

We measured pixel intensities in 10-15 small regions within each of 41 clones and compared intensities in each $\mathrm{ras}^{-/-}$region to a neighboring wild-type region. The ratio of average pixel intensity $\mathrm{ras}^{-/-} /$average pixel intensity $\mathrm{ras}^{+/-}$or $\mathrm{ras}^{+/+}$was calculated for each region, and the average ratio was calculated for each clone. The regions were selected to evenly sample pixel intensities throughout each clone. Because each region was relatively small, endogenous dMyc levels and tissue folds were usually similar for a region both inside and outside of the clone, thereby minimizing confounding bias due to these variables. There was no significant difference between $\mathrm{ras}^{+/-}$and $\mathrm{ras}^{+/+}$ average pixel intensities. Pixel intensities were measured using the histogram function of Adobe Photoshop.

\section{Acknowledgments}

We thank Wendy Lockwood and Steve Cohen for providing us with the tGPH stock prior to publication. We also thank Celeste
Berg, Ulrike Gaul, Ernst Hafen, Felix Karim, Sally Leevers, Hideyuki Okano, and Trudy Schupbach for fly stocks; Robert Eisenman, Rafael Fernandez, Peter Gallant, Juergen Knoblich, and Cynthia Yost for antibodies; Aida de la Cruz, Cristina Martin-Castellanos, Lenora Loo, Cecilia De Lorenzo, Amir Oryan, Kelly Plow, and Cynthia Yost for sharing unpublished data; Celeste Berg, Robert Eisenman, Savraj Grewal, and Tom Neufeld for comments on the manuscript; and members of the Edgar laboratory for helpful discussions during the course of this work. D.A.P. was a predoctoral fellow of the National Science Foundation and the Molecular Training Program in Cancer Research. Supported by NIH GMS R01-51186.

The publication costs of this article were defrayed in part by payment of page charges. This article must therefore be hereby marked "advertisement" in accordance with 18 USC section 1734 solely to indicate this fact.

\section{References}

Andersson, S., Saeboe-Larssen, S., Lambertsson, A., Merriam, J., and Jacobs-Lorena, M. 1994. A Drosophila third chromosome Minute locus encodes a ribosomal protein. Genetics 137: 513-520.

Barbacid, M. 1987. ras genes. Annu. Rev. Biochem. 56: 779-827.

Biggs, III, W.H. and Zipursky, S.L. 1992. Primary structure, expression, and signal-dependent tyrosine phosphorylation of a Drosophila homolog of extracellular signal-regulated kinase. Proc. Natl. Acad. Sci. 89: 6295-6299.

Boon, K., Caron, H.N., van Asperen, R., Valentijn, L., Hermus, M.C., van Sluis, P., Roobeek, I., Weis, I., Voute, P.A., Schwab, M., et al. 2001. N-myc enhances the expression of a large set of genes functioning in ribosome biogenesis and protein synthesis. EMBO J. 20: 1383-1393.

Boriack-Sjodin, P.A., Margarit, S.M., Bar-Sagi, D., and Kuriyan, J. 1998. The structural basis of the activation of Ras by Sos. Nature 394: 337-343.

Brand, A.H. and Perrimon, N. 1994. Raf acts downstream of the EGF receptor to determine dorsoventral polarity during Drosophila oogenesis. Genes \& Dev. 8: 629-639.

Britton, J.S. 2000. "Genetic and environmental control of growth and the cell cycle during larval development of Drosophila melanogaster." Ph.D. Thesis, University of Washington, Seattle, WA.

Britton, J.S., Lockwood, W.K., Li, L., Cohen, S.M., and Edgar, B.A. 2002. Drosophila's insulin/PI3-kinase pathway coordinates cellular metabolism with nutritional conditions. Dev. Cell 2: 239-249.

Brogiolo, W., Stocker, H., Ikeya, T., Rintelen, F., Fernandez, R., and Hafen, E. 2001. An evolutionarily conserved function of the Drosophila insulin receptor and insulin-like peptides in growth control. Curr. Biol. 11: 213-221.

Cantley, L.C. and Neel, B.G. 1999. New insights into tumor suppression: PTEN suppresses tumor formation by restraining the phosphoinositide 3-kinase/AKT pathway. Proc. Nat1. Acad. Sci. 96: 4240-4245.

Coller, H.A., Grandori, C., Tamayo, P., Colbert, T., Lander, E.S., Eisenman, R.N., and Golub, T.R. 2000. Expression analysis with oligonucleotide microarrays reveals that MYC regulates genes involved in growth, cell cycle, signaling, and adhesion. Proc. Natl. Acad. Sci. 97: 3260-3265.

de Alboran, I.M., O'Hagan, R.C., Gartner, F., Malynn, B., Davidson, L., Rickert, R., Rajewsky, K., DePinho, R.A., and Alt, F.W. 2001. Analysis of C-MYC function in normal cells via conditional gene-targeted mutation. Immunity 14: 45-55.

Diaz-Benjumea, F.J. and Hafen, E. 1994. The sevenless signal- 
ling cassette mediates Drosophila EGF receptor function during epidermal development. Development 120: 569-578.

Dominguez, M., Wasserman, J.D., and Freeman, M. 1998. Multiple functions of the EGF receptor in Drosophila eye development. Curr. Biol. 8: 1039-1048.

Douglas, N.C., Jacobs, H., Bothwell, A.L., and Hayday, A.C. 2001. Defining the specific physiological requirements for c-Myc in T cell development. Nat. Immunol. 2: 307-315.

Ferguson, K.M., Kavran, J.M., Sankaran, V.G., Fournier, E., Isakoff, S.J., Skolnik, E.Y., and Lemmon, M.A. 2000. Structural basis for discrimination of 3-phosphoinositides by pleckstrin homology domains. Mol. Cell 6: 373-384.

Gabay, L., Seger, R., and Shilo, B.Z. 1997. In situ activation pattern of Drosophila EGF receptor pathway during development. Science 277: 1103-1106.

Gille, H. and Downward, J. 1999. Multiple ras effector pathways contribute to G(1) cell cycle progression. J. Biol. Chem. 274: 22033-22040.

Grandori, C., Cowley, S.M., James, L.P., and Eisenman, R.N. 2000. The Myc/Max/Mad network and the transcriptional control of cell behavior. Annu. Rev. Cell. Dev. Biol. 16: 653699

Gray, A., Van Der Kaay, J., and Downes, C.P. 1999. The pleckstrin homology domains of protein kinase B and GRP1 (general receptor for phosphoinositides-1) are sensitive and selective probes for the cellular detection of phosphatidylinositol 3,4-bisphosphate and/or phosphatidylinositol 3,4,5trisphosphate in vivo. Biochem. J. 344 Pt 3: 929-936.

Guichard, A., Biehs, B., Sturtevant, M.A., Wickline, L., Chacko, J., Howard, K., and Bier, E. 1999. rhomboid and Star interact synergistically to promote EGFR/MAPK signaling during Drosophila wing vein development. Development 126: 2663-2676.

Guo, Q.M., Malek, R.L., Kim, S., Chiao, C., He, M., Ruffy, M., Sanka, K., Lee, N.H., Dang, C.V., and Liu, E.T. 2000. Identification of c-myc responsive genes using rat cDNA microarray. Cancer Res. 60: 5922-5928.

Halfar, K., Rommel, C., Stocker, H., and Hafen, E. 2001. Ras controls growth, survival and differentiation in the Drosophila eye by different thresholds of MAP kinase activity. Development 128: 1687-1696.

Han, M. and Sternberg, P.W. 1990. let-60, a gene that specifies cell fates during $C$. elegans vulval induction, encodes a ras protein. Cell 63: 921-931.

Hanahan, D. and Weinberg, R.A. 2000. The hallmarks of cancer. Cell 100: $57-70$.

Hay, B.A., Wolff, T., and Rubin, G.M. 1994. Expression of baculovirus P35 prevents cell death in Drosophila. Development 120: $2121-2129$.

Heumann, R., Goemans, C., Bartsch, D., Lingenhohl, K., Waldmeier, P.C., Hengerer, B., Allegrini, P.R., Schellander, K., Wagner, E.F., Arendt, T., et al. 2000. Transgenic activation of Ras in neurons promotes hypertrophy and protects from lesion-induced degeneration. J. Cell. Biol. 151: 1537-1548.

Huang, H., Potter, C.J., Tao, W., Li, D.M., Brogiolo, W., Hafen, E., Sun, H., and Xu, T. 1999. PTEN affects cell size, cell proliferation and apoptosis during Drosophila eye development. Development 126: 5365-5372.

Hunter, J.J., Tanaka, N., Rockman, H.A., Ross, Jr., J., and Chien, K.R. 1995. Ventricular expression of a MLC-2v-ras fusion gene induces cardiac hypertrophy and selective diastolic dysfunction in transgenic mice. J. Biol. Chem. 270: 2317323178.

Iritani, B.M. and Eisenman, R.N. 1999. c-Myc enhances protein synthesis and cell size during B lymphocyte development. Proc. Natl. Acad. Sci. 96: 13180-13185.
Johnson, L., Greenbaum, D., Cichowski, K., Mercer, K., Murphy, E., Schmitt, E., Bronson, R.T., Umanoff, H., Edelmann, W., Kucherlapati, R., et al. 1997. K-ras is an essential gene in the mouse with partial functional overlap with N-ras. Genes \& Dev. 11: 2468-2481.

Johnston, L.A., Prober, D.A., Edgar, B.A., Eisenman, R.N., and Gallant, P. 1999. Drosophila myc regulates cellular growth during development. Cell 98: 779-790.

Karim, F.D. and Rubin, G.M. 1998. Ectopic expression of activated Ras1 induces hyperplastic growth and increased cell death in Drosophila imaginal tissues. Development 125: 1-9.

Kauffmann-Zeh, A., Rodriguez-Viciana, P., Ulrich, E., Gilbert, C., Coffer, P., Downward, J., and Evan, G. 1997. Suppression of c-Myc-induced apoptosis by Ras signalling through PI(3)K and PKB. Nature 385: 544-548.

Kim, S., Li, Q., Dang, C.V., and Lee, L.A. 2000. Induction of ribosomal genes and hepatocyte hypertrophy by adenovirusmediated expression of c-Myc in vivo. Proc. Natl. Acad. Sci. 97: 11198-11202.

Kinashi, T., Katagiri, K., Watanabe, S., Vanhaesebroeck, B., Downward, J., and Takatsu, K. 2000. Distinct mechanisms of alpha $5 \beta 1$ integrin activation by Ha-Ras and R-Ras. J. Biol. Chem. 275: 22590-22596.

Koera, K., Nakamura, K., Nakao, K., Miyoshi, J., Toyoshima, K., Hatta, T., Otani, H., Aiba, A., and Katsuki, M. 1997. K-ras is essential for the development of the mouse embryo. Oncogene 15: 1151-1159.

Land, H., Parada, L.F., and Weinberg, R.A. 1983. Tumorigenic conversion of primary embryo fibroblasts requires at least two cooperating oncogenes. Nature 304: 596-602.

Lawrence, P.A., Casal, J., and Struhl, G. 1999. The hedgehog morphogen and gradients of cell affinity in the abdomen of Drosophila. Development 126: 2441-2449.

Leevers, S.J., Weinkove, D., MacDougall, L.K., Hafen, E., and Waterfield, M.D. 1996. The Drosophila phosphoinositide 3-kinase Dp110 promotes cell growth. EMBO J. 15: 65846594.

Lietzke, S.E., Bose, S., Cronin, T., Klarlund, J., Chawla, A., Czech, M.P., and Lambright, D.G. 2000. Structural basis of 3-phosphoinositide recognition by pleckstrin homology domains. Mol. Cell 6: 385-394.

Martin-Blanco, E., Roch, F., Noll, E., Baonza, A., Duffy, J.B., and Perrimon, N. 1999. A temporal switch in DER signaling controls the specification and differentiation of veins and interveins in the Drosophila wing. Development 126: 5739-5747.

Martin-Castellanos, C. and Edgar, B.A. 2002. A characterization of the effects of Dpp signaling on cell growth and proliferation in the Drosophila wing. Development 129: 1003-1013.

Morrison, D.K. and Cutler, R.E. 1997. The complexity of Raf-1 regulation. Curr. Opin. Cell. Biol. 9: 174-179.

Neufeld, T.P., de la Cruz, A.F., Johnston, L.A., and Edgar, B.A. 1998. Coordination of growth and cell division in the Drosophila wing. Cell 93: 1183-1193.

Neuman-Silberberg, F.S., Schejter, E., Hoffmann, F.M., and Shilo, B.Z. 1984. The Drosophila ras oncogenes: Structure and nucleotide sequence. Cell 37: 1027-1033.

Oatey, P.B., Venkateswarlu, K., Williams, A.G., Fletcher, L.M., Foulstone, E.J., Cullen, P.J., and Tavare, J.M. 1999. Confocal imaging of the subcellular distribution of phosphatidylinositol 3,4,5-trisphosphate in insulin- and PDGF-stimulated 3T3-L1 adipocytes. Biochem. J. 344 Pt 2: 511-518.

Pacold, M.E., Suire, S., Perisic, O., Lara-Gonzalez, S., Davis, C.T., Walker, E.H., Hawkins, P.T., Stephens, L., Eccleston, J.F., and Williams, R.L. 2000. Crystal structure and functional analysis of Ras binding to its effector phosphoinositide 3-kinase $\gamma$. Cell 103: 931-943. 
Peyssonnaux, C., Provot, S., Felder-Schmittbuhl, M.P., Calothy, G., and Eychene, A. 2000. Induction of postmitotic neuroretina cell proliferation by distinct Ras downstream signaling pathways. Mol. Cell. Biol. 20: 7068-7079.

Pignoni, F. and Zipursky, S.L. 1997. Induction of Drosophila eye development by decapentaplegic. Development 124: 271278.

Prober, D.A. and Edgar, B.A. 2000. Ras1 promotes cellular growth in the Drosophila wing. Cell 100: 435-446.

- 2001. Growth regulation by oncogenes-new insights from model organisms. Curr. Opin. Genet. Dev. 11: 19-26.

Queenan, A.M., Ghabrial, A., and Schupbach, T. 1997. Ectopic activation of torpedo/Egfr, a Drosophila receptor tyrosine kinase, dorsalizes both the eggshell and the embryo. Development 124: 3871-3880.

Rodriguez-Viciana, P., Warne, P.H., Dhand, R., Vanhaesebroeck, B., Gout, I., Fry, M.J., Waterfield, M.D., and Downward, J. 1994. Phosphatidylinositol-3-OH kinase as a direct target of Ras. Nature 370: 527-532.

Rodriguez-Viciana, P., Warne, P.H., Khwaja, A., Marte, B.M., Pappin, D., Das, P., Waterfield, M.D., Ridley, A., and Downward, J. 1997. Role of phosphoinositide 3-OH kinase in cell transformation and control of the actin cytoskeleton by Ras. Cell 89: 457-467.

Rommel, C. and Hafen, E. 1998. Ras-a versatile cellular switch. Curr. Opin. Genet. Dev. 8: 412-418.

Rulifson, E.J., Kim, S.K., and Nusse, R. 2002. Ablation of insulin-producing neurons in flies: Growth and diabetic phenotypes. Science 296: 1118-1120.

Saltiel, A.R. and Kahn, C.R. 2001. Insulin signalling and the regulation of glucose and lipid metabolism. Nature 414: 799806.

Sawamoto, K., Winge, P., Koyama, S., Hirota, Y., Yamada, C., Miyao, S., Yoshikawa, S., Jin, M.H., Kikuchi, A., and Okano, H. 1999. The Drosophila Ral GTPase regulates developmental cell shape changes through the Jun $\mathrm{NH}(2)$-terminal kinase pathway. J. Cell. Biol. 146: 361-372.

Schaefer, M., Petronczki, M., Dorner, D., Forte, M., and Knoblich, J.A. 2001. Heterotrimeric G proteins direct two modes of asymmetric cell division in the Drosophila nervous system. Cell 107: 183-194.

Schnorr, J.D. and Berg, C.A. 1996. Differential activity of Ras1 during patterning of the Drosophila dorsoventral axis. Genetics 144: 1545-1557.

Sears, R., Nuckolls, F., Haura, E., Taya, Y., Tamai, K., and Nevins, J.R. 2000. Multiple Ras-dependent phosphorylation pathways regulate Myc protein stability. Genes \& Dev. 14: 2501-2514.

Shioi, T., Kang, P.M., Douglas, P.S., Hampe, J., Yballe, C.M., Lawitts, J., Cantley, L.C., and Izumo, S. 2000. The conserved phosphoinositide 3-kinase pathway determines heart size in mice. EMBO J. 19: 2537-2548.

Simons, K. and Toomre, D. 2000. Lipid rafts and signal transduction. Nat. Rev. Mol. Cell. Biol. 1:31-39.

Sinn, E., Muller, W., Pattengale, P., Tepler, I., Wallace, R., and Leder, P. 1987. Coexpression of MMTV/v-Ha-ras and MMTV/c-myc genes in transgenic mice: Synergistic action of oncogenes in vivo. Cell 49: 465-475.

Struhl, G. and Basler, K. 1993. Organizing activity of wingless protein in Drosophila. Cell 72: 527-540.

Trumpp, A., Refaeli, Y., Oskarsson, T., Gasser, S., Murphy, M., Martin, G.R., and Bishop, J.M. 2001. c-Myc regulates mammalian body size by controlling cell number but not cell size. Nature 414: 768-773.

Umanoff, H., Edelmann, W., Pellicer, A., and Kucherlapati, R. 1995. The murine $\mathrm{N}$-ras gene is not essential for growth and development. Proc. Natl. Acad. Sci. 92: 1709-1713.

Vanhaesebroeck, B., Leevers, S.J., Ahmadi, K., Timms, J., Katso, R., Driscoll, P.C., Woscholski, R., Parker, P.J., and Waterfield, M.D. 2001. Synthesis and function of 3-phosphorylated inositol lipids. Annu. Rev. Biochem. 70: 535-602.

Weinkove, D., Neufeld, T.P., Twardzik, T., Waterfield, M.D., and Leevers, S.J. 1999. Regulation of imaginal disc cell size, cell number and organ size by Drosophila class I(A) phosphoinositide 3-kinase and its adaptor. Curr. Biol. 9: 10191029.

White, M.A., Nicolette, C., Minden, A., Polverino, A., Van Aelst, L., Karin, M., and Wigler, M.H. 1995. Multiple Ras functions can contribute to mammalian cell transformation. Cell 80: $533-541$.

Woods, D.F., Wu, J.W., and Bryant, P.J. 1997. Localization of proteins to the apico-lateral junctions of Drosophila epithelia. Dev. Genet. 20: 111-118.

$\mathrm{Xu}, \mathrm{T}$. and Rubin, G.M. 1993. Analysis of genetic mosaics in developing and adult Drosophila tissues. Development 117: 1223-1237.

Yan, J., Roy, S., Apolloni, A., Lane, A., and Hancock, J.F. 1998. Ras isoforms vary in their ability to activate Raf-1 and phosphoinositide 3-kinase. J. Biol. Chem. 273: 24052-24056.

Zaffran, S., Chartier, A., Gallant, P., Astier, M., Arquier, N., Doherty, D., Gratecos, D., and Semeriva, M. 1998. A Drosophila RNA helicase gene, pitchoune, is required for cell growth and proliferation and is a potential target of d-Myc. Development 125: 3571-3584.

Zhong, J., Troppmair, J., and Rapp, U.R. 2001. Independent control of cell survival by Raf-1 and Bcl-2 at the mitochondria Oncogene 20: 4807-4816. 


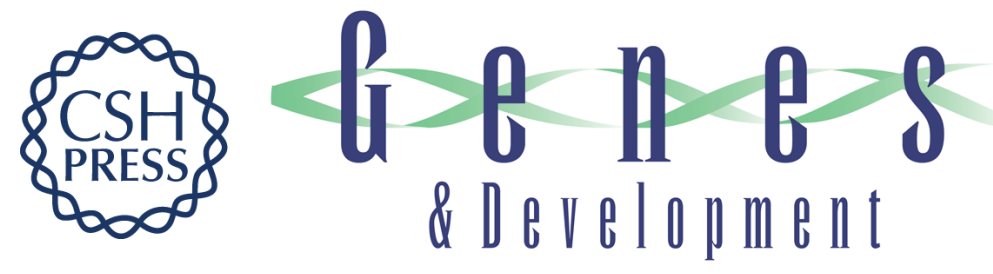

\section{Interactions between Ras1, dMyc, and dPI3K signaling in the developing Drosophila wing}

David A. Prober and Bruce A. Edgar

Genes Dev. 2002, 16:

Access the most recent version at doi:10.1101/gad.991102

Supplemental http://genesdev.cshlp.org/content/suppl/2002/09/12/16.17.2286.DC1
Material

References This article cites 73 articles, 36 of which can be accessed free at: http://genesdev.cshlp.org/content/16/17/2286.full.html\#ref-list-1

License

Email Alerting Receive free email alerts when new articles cite this article - sign up in the box at the top right Service corner of the article or click here.

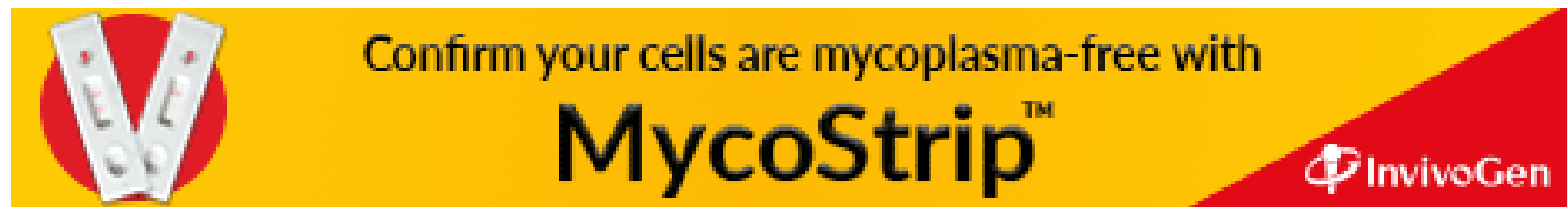

